\title{
Comparative Distribution of Dopamine D-1 and D-2 Receptors in the Basal Ganglia of Turtles, Pigeons, Rats, Cats, and Monkeys
}

ERIC K. RICHFIELD, ANNE B. YOUNG, AND JOHN B. PENNEY

Department of Neurology, University of Michigan, Ann Arbor, Michigan 48104

\begin{abstract}
The distribution and density of dopamine D-1 and D-2 receptors were studied in the basal ganglia of adult turtles, pigeons, rats, cats, and monkeys. Dopamine receptors were measured in vitro by quantitative autoradiography in alternate sections processed for D-1 and D-2 receptor subtypes and compared to adjacent sections stained for acetylcholinesterase ( $\mathrm{AChE}$ ) activity. [ ${ }^{3} \mathrm{H}$ ]-SCH 23390 and $\left[{ }^{3} \mathrm{H}\right]$-spiroperidol were used to label the D-1 and D.2 dopamine receptor subtypes, respectively.

The anatomic distribution of both D-1 and D-2 receptors in the basal ganglia was remarkably similar across all species examined. Whereas the absolute number of D-1 and D-2 receptors in the basal ganglia varied between species, the percentage of D-1 and D-2 receptors in a region was quite similar among species.

The pattern of binding to the D-1 and D-2 receptor varied among the different species. The adult turtles, pigeons, and rats demonstrated nonpatchy $\mathrm{D}-1$ and $\mathrm{D}-2$ receptor binding in the striatum and pallidum. The adult cat and monkey caudate nucleus and putamen demonstrated mildly heterogeneous receptor binding in a pattern that differed from that seen with AChE staining, but did occasionally demonstrate similar patterns of the D-1 and D-2 receptor subtypes. The immature cat striatum was characterized by heterogeneous D-1 receptor binding that corresponded to heterogeneous AChE rich patches, whereas D-2 receptor binding was homogeneous.

Heterogeneous binding was seen in other basal ganglia structures including the nucleus accumbens, olfactory tubercle, and substantia nigra pars compacta and reticulata. Complementary D-1 and D-2 receptor binding patterns were seen in the pallidum and substantia nigra of the mammals.

The results of this study indicate that both D-1 and D-2 dopamine receptors are present in the basal ganglia of five different vertebrates. A common feature of dopamine receptors in the basal ganglia is their heterogeneity in distribution and density. The heterogeneity of dopamine receptors has similarities to and differences from the distribution of presynaptic dopamine and other neurotransmitter markers of the basal ganglia.
\end{abstract}

Key words: ontogeny, acetylcholinesterase staining, striosome 
The basal ganglia are phylogenetically old regions of the central nervous system found in diverse groups of vertebrates, ${ }^{1}$ including reptiles, birds, and mammals (Reiner et al., '84; Parent, '86). A major ascending afferent pathway connects the mesencephalic substantia nigra with more rostral telencephalic regions including the basal ganglia. Dopamine, the major neurotransmitter of this pathway, is released in the basal ganglia to interact with two types of dopamine receptors, designated D.1 and D.2.

Interest in the dopaminergic innervation of the basal ganglia has been extensive since the introduction of the monoamine histofluorescence technique in the 1960s (Dalström and Fuxe, '64; Anden et al., '64). This technique allowed the detailed definition of the anatomic distribution of dopamine (DA) inputs into the basal ganglia and other regions of the cerebrum. Monoamine histofluorescence demonstrates a pattern in the striatum of birds and reptiles that is similar to that seen in mammals (Reiner et al., '84). It would not be surprising if the distributions and densities of dopamine receptor subtypes were also similar.

Recent anatomical studies using a variety of techniques have demonstrated that some structures of the basal ganglia are not homogeneous, as was once thought (Graybiel and Ragsdale, '78; Goldman-Rakic, '81). Different neurotransmitter systems have been shown to have a heterogeneous distribution in the striatum of both rats and higher mammals (Herkenham and Pert, '81; Graybiel et al., '8la,b; Gerfen, '84). Dopamine histofluorescence studies have shown that islands of strong fluorescence exist against a background of light fluorescence in the developing brain of mammals (Graybiel, '84). This pattern changes, becoming homogeneous in the adult, but can be pharmacologically changed to a heterogeneous pattern with the use of enzyme inhibitors (Olson et al., '72). The DA islands have been shown to be congruent with markers for the cholinergic system; AChE staining and cholinergic receptor autoradiography (Nastuk and Graybiel, '85). A variety of other neurotransmitter markers have subsequently been studied in relation to the patterns seen for DA and AChE staining. In some cases, there have been very good correspondences, including the opiate system (Graybiel et al., '81a). The pattern is different, however, with markers for substance $P$ and somatostatin, in which there is a variable or poor correspondence to $\mathrm{AChE}$ staining (Graybiel et al., '81a). In many of these studies, markers of presynaptic activity, such as a neurotransmitter or a synthesizing enzyme, have been used.

In a few cases, postsynaptic receptors have been studied (Herkenham and Pert, '81; Nastuk and Graybiel, '85). Since mismatches between a neurotransmitter and its receptor have been reported for different systems in various areas of the nervous system (Herkenham and McLean, '86; Kuhar et al., '86), it is important to compare pre- and postsynaptic markers for each neurotransmitter system before the functional significance of a heterogeneity can be known. In the case of the DA system, most receptor studies have focused on the rat brain, where no "patchy" heterogeneity has been found, although a different type of heterogeneity has been reported. Gradients in D-2 receptor binding from rostral to caudal and medial to lateral have been reported in rats, but may be controversial (Joyce et al., '85; Nock et al., '86). In some cases, the receptor gradient does not match dopamine levels (Joyce et al., '85). The relationships of receptor gradients to the "patchy" heterogeneities seen with dopamine histofluorescence and opiate receptors are not known.
The dopamine receptor has been divided into two subtypes, designated D-1 and D-2 (Stoof and Kebabian, '84). Although other dopamine receptor subtypes have been reported, they are thought to represent different affinity states for the D-1 and D-2 receptors. The distribution of the D-2 receptor has been studied in detail in the rat, but few studies have addressed possible binding heterogeneities in higher mammals. The D-1 receptor has not been studied in detail because of the lack of a selective compound for binding studies. The recent introduction of [ $\left.{ }^{3} \mathrm{H}\right]$-SCH 23390 has made it possible to study the autoradiographic distribution of the D-1 receptor (Dawson et al., '85, 86).

In this study, a direct comparison of the density and pattern of D-1 and D-2 receptors is made in the basal ganglia of a variety of vertebrates. The pattern of binding is compared to a well-established marker of striatal compartments, AChE staining. The pattern of receptor binding is also compared in immature and adult cats to study the changes that occur during development. The pattern of dopamine receptor binding is discussed in relation to previously observed patterns of presynaptic dopamine markers in the basal ganglia.

\section{METHODS}

Brains were obtained from one adult turtle (Pseudemys scripta), one adult white Carneaux pigeon (Columba livia), twenty adult male Sprague-Dawley albino rats, and four kittens (Felis domesticus) aged postnatal day $0(\mathrm{P}-0)$ to postnatal day 7 (P-7) by rapid decapitation. Brains were ob. tained from three adult male cats (Felis domesticus) and four adult male cynomolgus monkeys (Macaca fasicularis) following an overdose of sodium pentobarbital. Brains from all animals, except the monkeys, were frozen by using crushed dry ice and mounted on tissue pedestals with Lipshaw embedding matrix. Monkey blocks were frozen by slow immersion into liquid isopentane at $-80^{\circ} \mathrm{C}$. Brains were stored at $-70^{\circ} \mathrm{C}$ until sectioned. Brains were warmed to -10 to $-20^{\circ} \mathrm{C}$, and coronal sections of 20 or $30 \mu \mathrm{M}$ were cut on a Lipshaw cryostat microtome and were then thawmounted onto gelatin-coated (subbed) slides. The slides were dehydrated on a warming plate at $30^{\circ} \mathrm{C}$ and then stored at $-20^{\circ} \mathrm{C}$ until used in assays.

Both the D.1 and D.2 receptor assays were carried out in a $25 \mathrm{mM}$ Tris- $\mathrm{HCl}$ buffer ( $\mathrm{pH} 7.5$ ) containing $100 \mathrm{mM} \mathrm{NaCl}$, $1 \mathrm{mM} \mathrm{MgCl}{ }_{2}, 1 \mu \mathrm{M}$ pargyline, and $0.001 \%$ ascorbate. Slides used for receptor autoradiography were warmed to room temperature for 1 hour, then incubated with tritiated ligand at room temperature, given a $1 \times 10$ minute wash in

${ }^{1}$ Whereas there is still no generally accepted definition of the basal ganglia, most anatomists agree that the caudate nucleus, putamen, and pallidum (medial and lateral globus pallidus) are the major components. For the purpose of this paper, we also include the claustrum, and substantia nigra pars compacta (SNC) and pars reticulata (SNR) as part of the BG. Different names have been applied to the different pallidal segments in mammals. We generally use the designation of medial globus pallidus (MGP) to refer to the entopeduncular nucleus (EP) of the rat and cat, and lateral globus pallidus (LGP) to refer to the globus pallidus (GP) of rat and cat. The terminology for homologous brain regions differs among the various groups of vertebrates described in this paper. In addition, controversy persists whether some regions are homologous between birds, reptiles, and mammals. For our purposes, we follow the homologues discussed by Reiner and Carraway ( 87 ). 
buffer at $4^{\circ} \mathrm{C}$ and dipped in distilled water for 3 seconds. Slides were dried with a stream of cool air. Dried slides were placed in an $x$-ray cassette with ${ }^{14} \mathrm{C}$ plastic standards previously calibrated with ${ }^{3} \mathrm{H}$ brain paste sections (Penney et al., '81; Pan et al., '83; Penney and Pan, '86) and exposed to LKB Ultrofilm ${ }^{3} \mathrm{H}$ at $4^{\circ} \mathrm{C}$ for 10 to 21 days. The LKB Ultrofilm ${ }^{3} \mathrm{H}$ was developed in Kodak D19 for 3 minutes at room temperature and fixed in Kodak rapid fix for 3.5 minutes.

The D-1 assay used [ $\left.{ }^{3} \mathrm{H}\right]-\mathrm{SCH} 23390$ to label the receptor. Kinetic, competition, and saturation experiments were performed with $20-\mu \mathrm{M}$ thick sections from the rat striatum. Kinetic studies were performed for the D. 1 receptor at a $\left.{ }^{3} \mathrm{H}\right]-\mathrm{SCH} 23390$ concentration of $0.2 \mathrm{nM}$, in which the association time varied from 5 to 180 minutes and the dissociation time varied from 15 to 300 minutes by using the method of infinite dilution. Saturation studies were performed with concentrations of $\left[{ }^{3} \mathrm{H}\right]-\mathrm{SCH} 23390$ from 0.05 to $5.0 \mathrm{nM}$. Competition and distribution studies were performed at a $\left[{ }^{3} \mathrm{H}\right]-\mathrm{SCH} 23390$ concentration equal to the $\mathrm{K}_{\mathrm{D}}(0.57 \mathrm{nM})$. Specific binding was determined by subtracting the amount bound in the presence of $1 \mu \mathrm{M}$ cis-flupentixol (nonspecific) from the total amount bound. Competition studies were carried out using conditions described except that varying concentrations of unlabeled drug were included in the assay.

The D-2 receptor assay used $\left[{ }^{3} \mathrm{H}\right]$-spiroperidol as previously described (Richfield et al., '86,87), except for slight modifications. The buffer was changed to that described above and the incubation time was 120 minutes. Specific binding was determined by subtracting the nonspecific binding in the presence of $10 \mu \mathrm{M}$ dopamine from the total amount bound.

All binding data were determined directly from film densities in regions of interest. Films were analyzed as previously described (Richfield et al,, '86; Penney et al., '81). The rat striatum was used to determine the binding parameters for both the D-1 and D-2 assays. Twenty readings from each area were averaged to determine the amount of ${ }^{3} \mathrm{H}$ label bound per mg of protein. In regions where the binding was heterogeneous, measurements were made for the average, high, and low values as determined by visual inspection.

Binding data from Scatchard curves in four rats, and distribution studies in four rats and the four monkeys were analyzed for right-left differences by t-test. If there was no right/left difference, the right and left values were averaged and are reported as a single value. Only one hemisphere from the kittens and cats was used for autoradiography, so right-left comparisons were not made.

Adjacent sections from the kitten, cat, and monkey brains were stained for AChE by the method of Geneser-Jensen and Blackstad ('71). Ethopropazine- $\mathrm{HCl}(0.2 \mathrm{mM})$ was added to the incubation medium to block pseudocholinesterase activity. Incubation time for the kittens varied from 60 to 90 minutes, for the adult cat and monkey from 30 to 45 minutes.

Adjacent sections from the monkeys and cats were stained with cresyl violet to verify anatomic areas. The atlases of Powers and Reiner ('80), Karten and Hodos ('67), Paxinos and Watson ('82), Snider and Lee ('81), and Snider and Niemer ('61) were used to identify structures in the brains of turtles, pigeons, rats, cats, and monkeys, respectively.

$\left[{ }^{3} \mathrm{H}\right.$ ]-SCH 23390 (specific activity 74 to $85 \mathrm{Ci} / \mathrm{mmol}$ ) and $\left[{ }^{3} \mathrm{H}\right]$-spiroperidol $(76 \mathrm{Ci} / \mathrm{mmol})$ were obtained from Amersham (Arlington Heights, IL). Mianserin was obtained from
Organon (Oss, The Netherlands), dopamine and apomorphine from Sigma (St. Louis, MO), SKF 38393 from Smith, Kline and French Laboratories (Philadelphia, PA), LY 171555 from Lilly Research Laboratories (Indianapolis, IN), cis-flupentixol from Dr. John Hyttel of H. Lundbeck and Co. (Copenhagen, Denmark) and sulpiride from Ph. Delagrange (Paris, France).

\section{RESULTS \\ D-1 and D-2 dopamine receptor assays}

Kinetic studies were performed by using $\left[{ }^{3} \mathrm{H}\right]-\mathrm{SCH} 23390$ to determine appropriate incubation and postincubation wash times (Fig. 1). The association rate constant $\left(k_{+1}\right)$ was $0.0048 \pm 0.0005 \mathrm{~min}^{-1} \mathrm{nM}^{-1}$ as determined by pseudo first-order kinetics (Bylund, '80). The dissociation rate constant $\left(\mathrm{k}_{-1}\right)$ was $0.0022 \pm 0.0001 \mathrm{~min}^{-1}$. The equilibrium dissociation constant $\left(\mathrm{K}_{\mathrm{D}}\right)$ as determined by the kinetic relationship $\left(k_{-1} / k_{+1}\right)$ was $0.46 \pm 0.04 \mathrm{nM}$, which is in close agreement with the value obtained by Scatchard analysis $(0.57 \mathrm{nM})$. Equilibrium occurred by 150 minutes, and one 10 -minute postincubation wash was adequate to provide a high degree of specific binding. Specific binding was $98-99 \%$ at a [ $\left.{ }^{3} \mathrm{H}\right]-\mathrm{SCH} 23390$ concentration of $0.55 \mathrm{nM}$ in the rat striatum. Specific binding fell to $78 \%$ of total bind. ing at a $\left[{ }^{3} \mathrm{H}\right]-\mathrm{SCH} 23390$ concentration of $5 \mathrm{nM}$ (Fig. 2).

Saturation studies with $\left[{ }^{3} \mathrm{H}\right]-\mathrm{SCH} 23390$ indicate that binding in the rat striatum was specific and saturable, and that nonspecific binding increased dramatically at concentrations of $2.5 \mathrm{nM}$ and greater. Scatchard analysis produced a $K_{D}$ value of $0.57 \pm 0.05 \mathrm{nM}$, a maximal number of binding sites $\left(B_{\max }\right)$ of $2.85 \pm 0.50 \mathrm{pmol} / \mathrm{mg}$ protein and a Hill coefficient $\left(n_{H}\right)$ of $0.95 \pm 0.01$ (Fig, 3). There was no difference between right and left striatal values for the $\mathrm{K}_{\mathrm{D}}$ or $\mathrm{B}_{\max }$.

\section{Abbreviations}

ACC nucleus accumbens

AChE acetylcholinesterase

ave average

$B_{\max }$ maximum number of binding sites

CAUD caudate nucleus

CLAUS claustrum

DA dopamine

dor dorsal

EP entopeduncular nucleus

GP globus pallidus

INP nucleus intrapeduncularis

dissociation rate constant association rate constant

equilibrium dissociation constant

lateral

lateral globus pallidus

lobus parolfactorius

medial

medial globus pallidus

Hill coefficient

bed nucleus of the stria terminalis

olfactory tubercle

paleostriatum augmentatum

postnatal day 0

postnatal day geven

paleostriatum primitivum

putamen

substantia nigra

substantia nigra pars compacta

substantia nigra pars reticulata

striatum

ventral

ventral pallidum

ventral tegmental area 


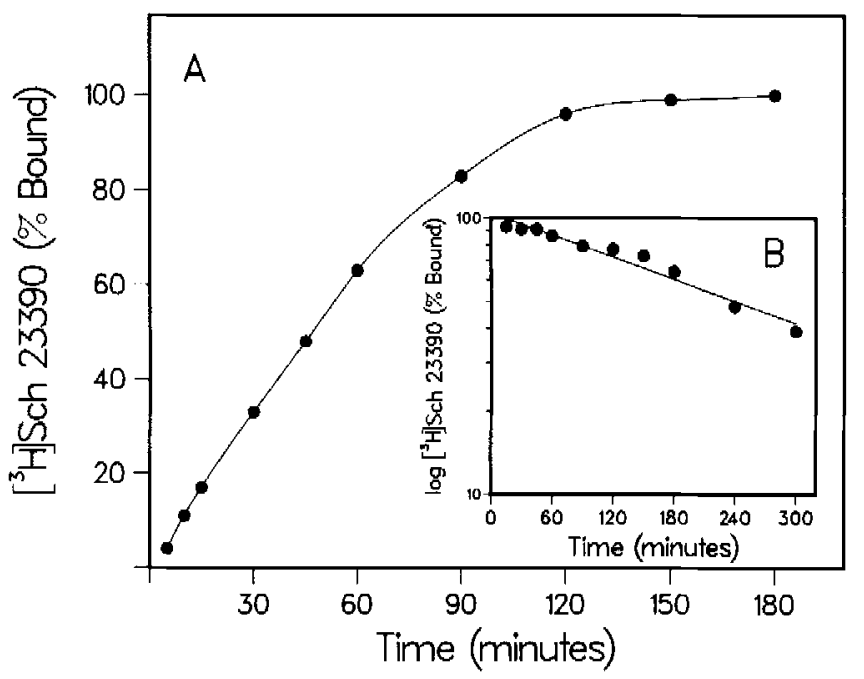

Fig. 1. Kinetic curves of $\left[{ }^{3} \mathrm{H}\right]-\mathrm{SCH} 23390$ binding in rat striatum. D.1 receptor autoradiography was performed using [ $\left.{ }^{3} \mathrm{H}\right]-\mathrm{SCH} 23390(0.2 \mathrm{nM})$ as described in the text. Binding was determined using quantitative autoradiography. Curves are representative of a single experiment and data points represent specific binding. Kinetic constants reported are the mean and standard deviation for three separate experiments. A. Association curve. The association rate constant $\left(k_{+1}\right)$ is $0.0048 \pm 0.0005 \mathrm{~min}^{-1} \mathrm{nM}^{-1}$ as determined by pseudo first-order kinetics. Equilibrium for other experiments occurs by 150 minutes. B. Dissociation curve. The dissociation rate constant $\left(k_{-1}\right)$ is $0.0022 \pm 0.0001 \mathrm{~min}^{-1}$.

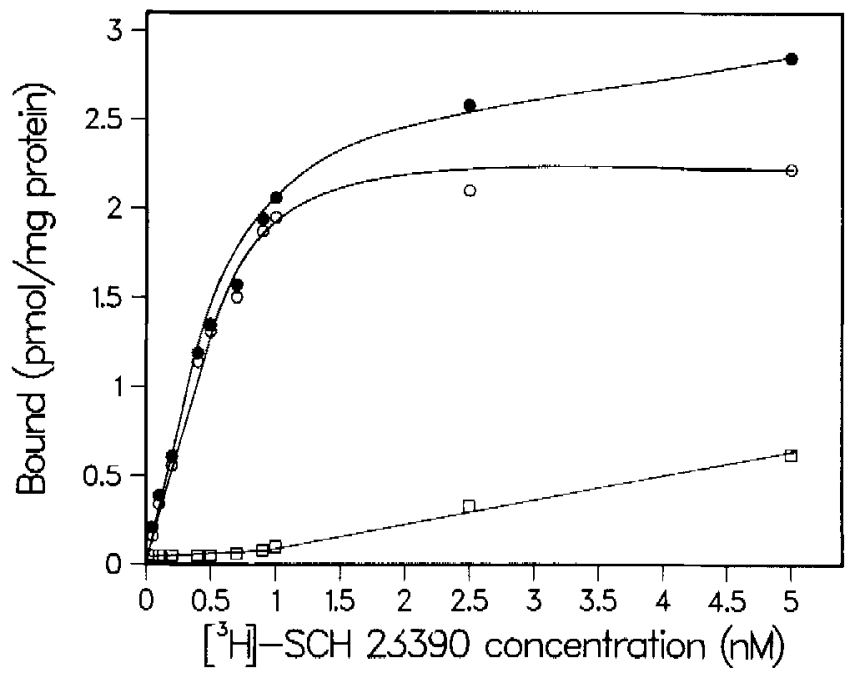

Fig. 2. Saturation curve of $\left[{ }^{3} \mathrm{H}\right]-\mathrm{SCH} 23390$ binding in rat striatum. D-1 receptor autoradiography was performed using $\left[{ }^{3} \mathrm{H}\right]-\mathrm{SCH} 23390(0.05$ to 5.0 nM) as described in the text. Total binding (filled circle) represents binding in the presence of $\left[{ }^{3} \mathrm{H}\right]-S C H ~ 23390$ alone, specific binding (open circle represents the amount of $\left[{ }^{3} \mathrm{H}\right]-\mathrm{SCH} 23390$ bound with nonspecific binding subtracted, and nonspecific binding (open square) represents binding in the presence of both $j^{3} \mathrm{H} J-S C H ~ 23390$ and 1 M cis-flupentixol. Nonspecific binding is very low at $\left({ }^{3} \mathrm{H}\right]$-SCH 23390 concentrations below 1 nM, but increased at concentrations greater than $1 \mathrm{nM}$, suggesting the ligand may bind to an additional site at higher concentrations. All experiments, except for saturation experiments, were performed at concentrations at or below $0.55 \mathrm{nM}$ to ensure binding to only the D-1 receptor.

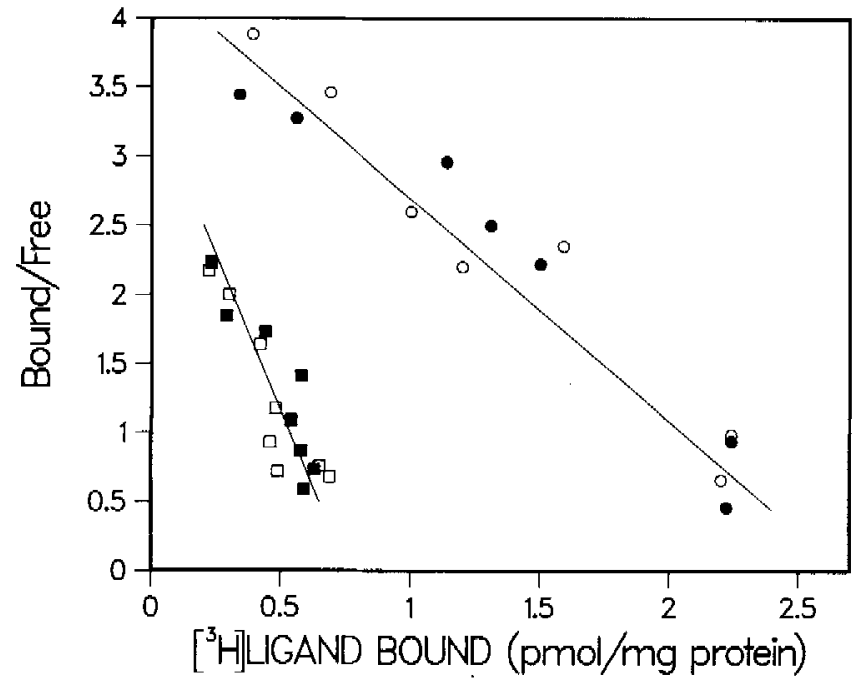

Fig. 3. Scatchard plot of $\left[{ }^{3} \mathbf{H}\right]$-SCH 23390 and $\left[{ }^{3} \mathrm{H}\right]$-spiroperidol binding in the rat striatum. Saturation experiments were performed using $\left[{ }^{3} \mathrm{H}\right]$ $\mathrm{SCH} 23390(0.05$ to $5.0 \mathrm{nM})$ to label the $\mathrm{D}-1$ receptor (circles) and ${ }^{3} \mathrm{H}$ spiroperidol $(0.05$ to $2.5 \mathrm{nM}$ ) in the presence of $0.1 \mu \mathrm{M}$ mianserin to label the D-2 receptor (squares) as described in the text. Curves are representative of a single experiment through the midstriatum. Right (open symbols) and left (filled symbols) striata were analyzed independently in four animals. No significant differences between sides were found for the $K_{D}$ or $B_{\max }$ for either receptor subtype. The $D-1$ receptor has a $K_{D}$ of $0.57 \pm 0.05$ $\mathrm{nM}$ and $\mathrm{B}_{\max }$ of $2.85 \pm 0.50 \mathrm{pmol} / \mathrm{mg}$ protein, whereas the $\mathrm{D}-2$ receptor has a $K_{D}$ of $0.26 \pm 0.04$ and $B_{\max }$ of $0.86 \pm 0.09 \mathrm{pmol} / \mathrm{mg}$ protein.

Competition studies using a variety of D-1 and D-2 selective compounds indicated that binding was selective for the D-1 receptor, in agreement with previous reports (Dawson et al., '86; Billard et al., '84; Hess et al., '86). Inhibitory constants $\left(\mathrm{K}_{\mathrm{I}}\right)$ and Hill coefficients $\left(\mathrm{n}_{\mathrm{H}}\right)$ were determined for the following compounds: SKF $3839337 \pm 6 \mathrm{nM}$ and 0.94 \pm 0.03 , cis-flupentixol $78 \pm 55 \mathrm{nM}$ and $0.98 \pm 0.06$, apomorphine $600 \pm 8 \mathrm{nM}$ and $1.09 \pm 0.4$, mianserin $1850 \pm$ $840 \mathrm{nM}$ and $0.95 \pm 0.05$, dopamine $1990 \pm 310 \mathrm{nM}$ and $0.93 \pm 0.19$, sulpiride $>100,000 \mathrm{nM}$ and $\mathrm{LY} 171555>$ $100,000 \mathrm{nM}$.

Scatchard analysis of $\left[{ }^{3} \mathrm{H}\right]$-spiroperidol binding revealed a $\mathrm{K}_{\mathrm{D}}$ of $0.25 \pm 0.04 \mathrm{nM}, \mathrm{a} \mathrm{B}_{\max }$ of $0.86 \pm 0.09 \mathrm{pmol} / \mathrm{mg}$ protein and $\mathrm{a} \mathrm{n}_{\mathrm{H}}$ of $1.02 \pm 0.02$. There were no significant right/left differences in any of these values. The specificity of this assay has been previously documented (Richfield et al., '86a; Altar et al., '85; Neve et al., '84). Specific binding for the D-2 receptor represented $85 \%$ of the total binding in the rat striatum at a concentration equal to the $K_{D}$.

The total number of dopamine receptors in the midportion of the rat striatum, as determined by adding the $B_{\max }$ values for the D-1 and D-2 receptors, was $3.71 \mathrm{pmol} / \mathrm{mg}$ protein. The percentages of D-1 and D-2 receptors, were $77 \%$ and $23 \%$, respectively. The percentages of receptor subtypes obtained with single concentration incubations at the $\mathrm{K}_{\mathrm{D}}$ values was $75 \%$ and $25 \%$ for $\mathrm{D}-1$ and $\mathrm{D}-2$ receptors in the same region, indicating that accurate percentages of dopamine receptor subtypes can be determined in various regions by using adjacent sections from the same animal. 

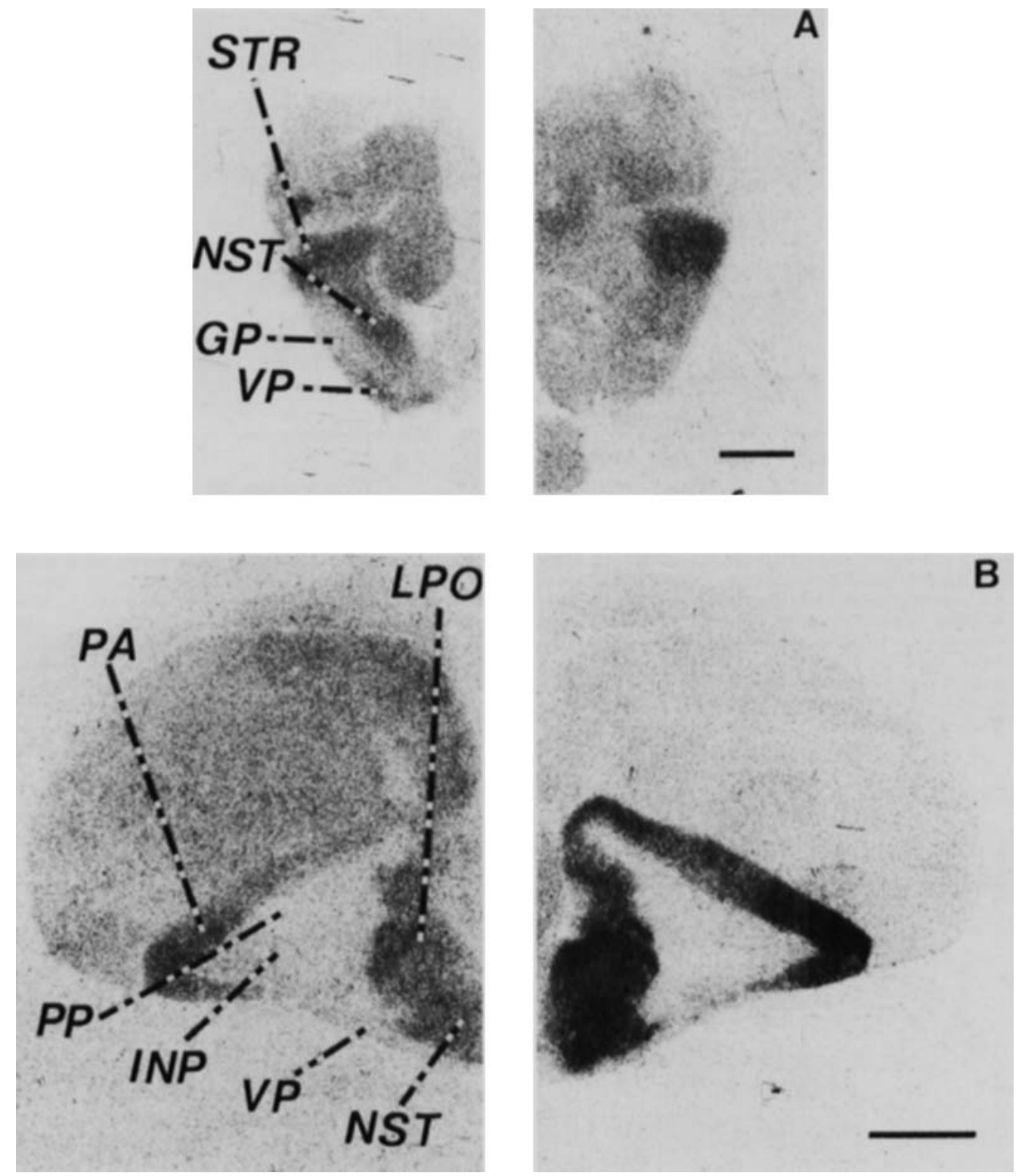

Fig. 4. Dopamine receptor binding in portions of the turtle and pigeon basal ganglia. D-1 and D-2 dopamine receptor autoradiography were performed through regions of the BG as described in the text. Adjacent section were incubated with tritiated ligand at their respective $K_{\mathrm{D}}$. Sections processed for D-1 receptor autoradiography were exposed to LKB Ultrofilm- ${ }^{3} \mathrm{H}$ for 10 to 14 days; those processed for D-2 receptor autoradiography were exposed for 14 to 21 days. The response of Ultrofilm- ${ }^{3} \mathrm{H}$ to tritium is nonlinear (Pan et al., '83). For these reasons, direct comparison of film density or

\section{Dopamine receptor distribution in the turtle and pigeon}

Dopamine receptors are present in the basal ganglia of both the turtle and pigeon (Fig. 4). D-1 dopamine receptors are present in the turtle striatum $(0.19 \mathrm{pmol} / \mathrm{mg}$ protein), bed nucleus of the stria terminalis $(0.18 \mathrm{pmol} / \mathrm{mg}$ protein), globus pallidus $(0.08 \mathrm{pmol} / \mathrm{mg}$ protein), ventral pallidum $(0.06 \mathrm{pmol} / \mathrm{mg}$ protein), and substantia nigra $(0.16 \mathrm{pmol} / \mathrm{mg}$ protein). D-2 dopamine receptors are present in the turtle striatum $(0.22 \mathrm{pmol} / \mathrm{mg}$ protein), bed nucleus of the stria

photographic density between receptor subtypes in adjacent sections cannot be made visually. Valid comparisons can be made using quantitative autoradiography as reported in the text. $\mathbf{A}$. Turtle dopamine receptor montage. Dopamine receptor autoradiograms through adjacent sections of turtle forebrain (D-1 left, D-2 right). B. Pigeon dopamine receptor montage. Dopamine receptor autoradiograms through adjacent sections of pigeon forebrain (D-1 left, D 2 right). Scale bar $=2 \mathrm{~mm}$

terminalis $(0.03 \mathrm{pmol} / \mathrm{mg}$ protein), and globus pallidus $(0.05$ $\mathrm{pmol} / \mathrm{mg}$ protein).

The pigeon brain contained D-1 receptors in the paleostriatum augmentum $(0.19 \mathrm{pmol} / \mathrm{mg}$ protein $)$, lobus parolfactorius $(0.20 \mathrm{pmol} / \mathrm{mg}$ protein), paleostriatum primitivum $(0.01 \mathrm{pmol} / \mathrm{mg}$ protein), nucleus intrapeduncularis $(0.01$ $\mathrm{pmol} / \mathrm{mg}$ protein), ventral pallidum $(0.01 \mathrm{pmol} / \mathrm{mg}$ protein), bed nucleus of the stria terminalis $(0.21 \mathrm{pmol} / \mathrm{mg}$ protein) and nucleus tegmenti pedunculopontis, pars compacta $(0.04$ $\mathrm{pmol} / \mathrm{mg}$ protein). D.2 dopamine receptors are also present in the pigeon paleostriatum augmentatum $(0.32 \mathrm{pmol} / \mathrm{mg}$ 
TABI,F 1. Summary of Rat Dopamine Receptor Distribution

\begin{tabular}{|c|c|c|c|c|c|c|}
\hline \multirow[b]{3}{*}{ Region } & \multicolumn{6}{|c|}{ Receptor subtype } \\
\hline & \multicolumn{3}{|c|}{ D-1 } & \multicolumn{3}{|c|}{ D-2 } \\
\hline & $\begin{array}{l}\text { Amount } \\
\text { bound } \\
\text { (pmol/mg } \\
\text { protein } \\
\pm S D)^{\mathrm{a}}\end{array}$ & $\begin{array}{l}\text { Amount } \\
\text { bound } \\
\text { relative to } \\
\text { midstriatum } \\
(\%)^{\mathrm{b}}\end{array}$ & $\begin{array}{l}\text { Amount } \\
\text { bound } \\
\text { relative } \\
\text { to total } \\
\text { dopamine } \\
\text { receptors } \\
(\%)^{c} \\
\end{array}$ & $\begin{array}{l}\text { Amount } \\
\text { bound } \\
\text { (pmol/mg } \\
\text { protein } \\
\pm S D)^{\mathrm{a}}\end{array}$ & $\begin{array}{l}\text { Amount } \\
\text { bound } \\
\text { relative to } \\
\text { midstriatum } \\
(\%)^{\mathrm{b}}\end{array}$ & $\begin{array}{c}\text { Amount } \\
\text { bound } \\
\text { relative to } \\
\text { total dopamine } \\
\text { receptors } \\
(\%)^{\circ}\end{array}$ \\
\hline \multicolumn{7}{|l|}{ Dorsal striatum } \\
\hline Rostral & $1.56 \pm 0.07$ & 102 & 74 & $0.56 \pm 0.02$ & 108 & 26 \\
\hline Mid & $1.53 \pm 0.05$ & 100 & 75 & $0.52 \pm 0.06$ & 100 & 25 \\
\hline Caudal & $1.36 \pm 0.08$ & 89 & 74 & $0.48 \pm 0.06$ & 92 & 26 \\
\hline Dorsal & $1.25 \bar{\perp} 0.13$ & 82 & 74 & $0.43 \pm 0.06$ & 83 & 26 \\
\hline Ventral & $1.60 \pm 0.01$ & 105 & 73 & $0.60 \pm 0.07$ & 115 & 27 \\
\hline \multicolumn{7}{|l|}{ Nucleus accumbens } \\
\hline Rostral & $1.63 \pm 0.05$ & 107 & 82 & $0.36 \pm 0.01$ & 69 & 18 \\
\hline Caudal & $0.90+0.08$ & 59 & 76 & $0.29 \pm 0.02$ & 56 & 24 \\
\hline \multicolumn{7}{|l|}{ Olfactory tubercle } \\
\hline Rostral & $1.58 \pm 0.06$ & 103 & 72 & $0.60 \pm 0.06$ & 107 & 28 \\
\hline Caudal & $1.64 \pm 0.08$ & 107 & 78 & $0.46 \pm 0.09$ & 82 & 22 \\
\hline Globus pallidus & $0.21 \pm 0.04$ & 14 & 84 & $0.04 \pm 0.01$ & 8 & 16 \\
\hline Entopeduncular nucleus & $0.56 \pm 0.09$ & 37 & 100 & ND & 0 & 0 \\
\hline Ventral palhidum & $0.65 \pm 0.17$ & 42 & 87 & $0.10 \pm 0.03$ & 19 & 13 \\
\hline \multicolumn{7}{|l|}{ Substantia nigra-compacta } \\
\hline Average & $1.51 \pm 0.10$ & 99 & 92 & $0.14 \pm 0.03$ & 27 & 8 \\
\hline Media] & $1.68 \pm 0.11$ & 110 & 90 & $0.19 \pm 0.05$ & 37 & 10 \\
\hline Lateral & $1.26 \pm 0.18$ & 82 & 94 & $0.08 \pm 0.03$ & 15 & 6 \\
\hline \multicolumn{7}{|l|}{ Substantia nigra-reticulata } \\
\hline Average & $1.40 \pm 0.13$ & 92 & 93 & $0.10 \pm 0.02$ & 19 & 7 \\
\hline Medial & $1.67+0.20$ & 109 & 92 & $0.14 \pm 0.03$ & 27 & 8 \\
\hline Lateral & $1.19 \pm 0.12$ & 78 & 94 & $0.07 \pm 0.03$ & 13 & 6 \\
\hline Claustrum & $0.40 \pm 0.09$ & 26 & 100 & ND & 0 & 0 \\
\hline
\end{tabular}

Values represent the avcrage specific binding from four animals $\_$standard deviation. Sections were incubated at concentrations of tritiated ligand equal to their respective $K_{1}$. "The amount bound relative to midstriatum is the amount of receptor binding in a region expressed at a pereentage relative to the amount present in the midstriatum.

"The amount bound relative to the total number of dopamine receptors is the amount of the dopamine receptor subtype present in a particular region exprefised as a percentage of the amount bound relative to the total number of dopamine receptor

$\mathrm{ND}=$ none detected.

protein), lobus parolfactorius $(0.33 \mathrm{pmol} / \mathrm{mg}$ protein), paleostriatum primitivum $(0.02 \mathrm{pmol} / \mathrm{mg}$ protein $)$, nucleus in trapeduncularis $(0.02 \mathrm{pmol} / \mathrm{mg}$ protein), ventral pallidum $(0.02 \mathrm{pmol} / \mathrm{mg}$ protein $)$, bed nucleus of the stria terminalis (0.42 $\mathrm{pmol} / \mathrm{mg}$ protein) and nucleus tegmenti pedunculopar. tis, pars compacta $(0.04 \mathrm{pmol} / \mathrm{mg}$ protein). The lateral portion of the paleostriatum augmentatum (PA) contained more D-1 and D-2 receptors than the medial portion. No "patchy" heterogeneities were observed.

\section{Dopamine receptor distribution in rats}

Dopamine receptors are present in all basal ganglia nuclei of the rat (Table 1). Neither the D-1 nor D-2 receptor demonstrated any "patchy" heterogeneities in the dorsal striatum (Fig. 5). The n. accumbens did have areas of higher and lower binding compared to the average for both the $\mathrm{D}$ 1 and $D-2$ receptor, whereas the olfactory tubercle had clear discontinuities in D-2 receptor binding. Both the D-1 and D-2 receptors did demonstrate two other types of heterogeneities, gradients and districts. The striatum had a decreasing receptor gradient from rostral to caudal on the order of $13-14 \%$ for both subtypes. The caudal striatum had an increasing gradient from dorsal to ventral on the order of 22 to $28 \%$. The rostral and midstriatum did not have dorsal to ventral gradients. No medial to lateral gradient was seen at any level for either receptor subtype. There was a district of slightly increased binding in the dorsomedial portion of the striatum for both the D-1 and D-2 recep- tor, which appeared to be distinct from the remainder of the striatum along its rostral to caudal extent. This area, along with the ventral portion of the caudal striatum, were the only regions of the striatum devoid of traversing white matter bundles. A decreasing rostral to caudal gradient was also seen in two structures that had no significant white matter tracts coursing through them, the nucleus accumbens and olfactory tubercle.

Districts of heterogenous binding were prominent in the endopenduncular nucleus (EP). The EP had increased binding along the margins and in the medial portion of the nucleus for the D-1 receptor. The SNK and SNC had increased receptor binding in the medial portion of the nucleus for both subtypes. The claustrum had a homogeneous pattern of D-1 receptor binding, without detectable D-2 receptor binding. The density of the D-1 receptor was quite similar among $\mathrm{BG}$ structures except for the pallidum and claustrum, which had 14 to $40 \%$ of the number of receptors compared to the midstriatal density. The D-2 receptor density varied more dramatically among basal ganglia structures; varying from undetectable in $\mathrm{EP}$ and claustrum, to 20 to $27 \%$ in SN, and $8-20 \%$ in globus pallidus (GP) and ventral pallidum (VP).

\section{Iopamine receptor distribution in neonatal and adult cats}

Dopamine receptors were present in the basal ganglia of neonatal and adult cats as previously reported (Richfield et 

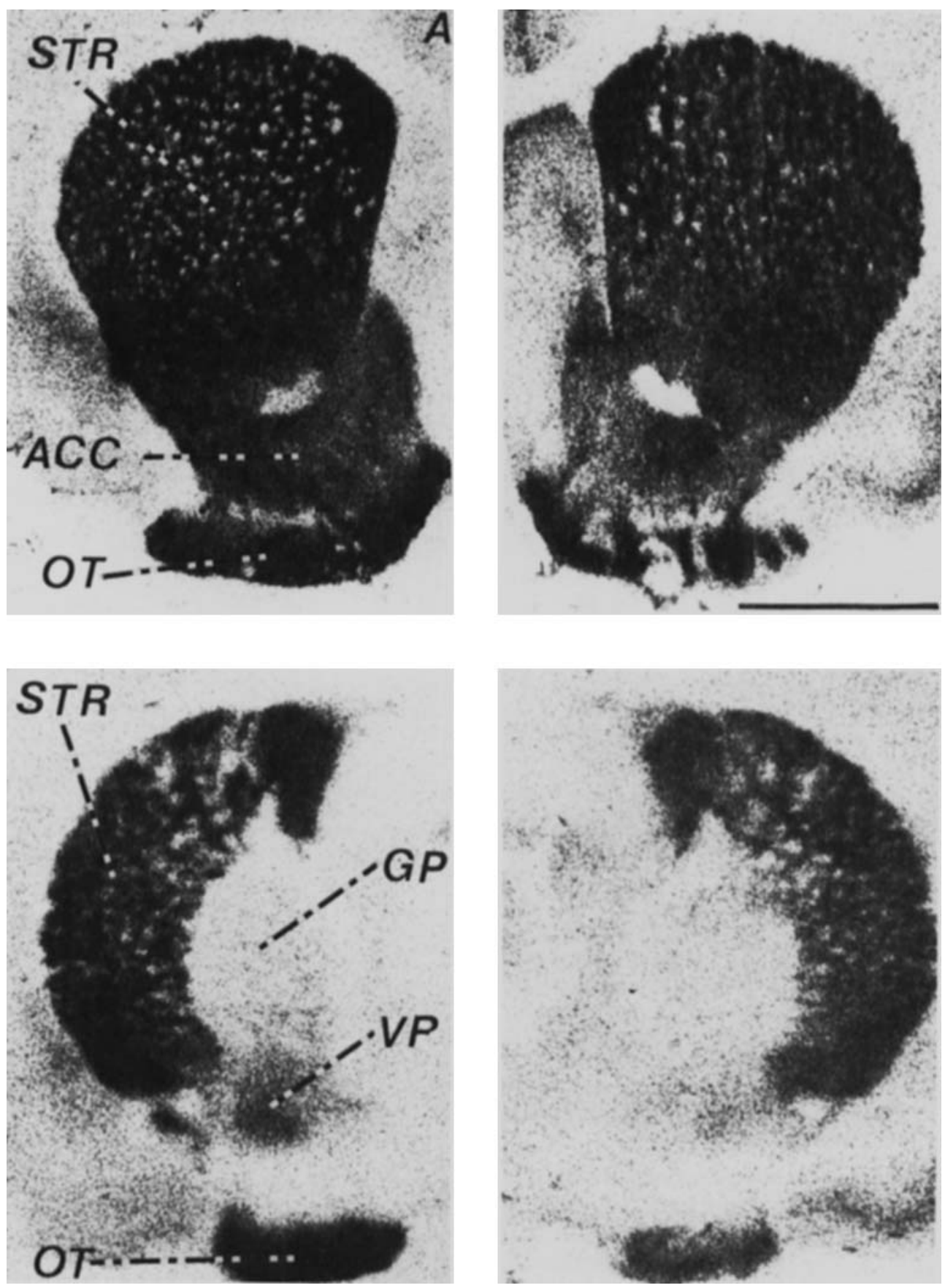

Fig. 5. Dopamine receptor montage in rat BG. Adjacent sections through various regions of the rat $\mathrm{BG}$ were processed for dopamine receptor autoradiography as described in the text and Figure 4. Receptor densities are reported in Table 1. $\boldsymbol{\Lambda}$. Sections through striatum and pallidum. Dopamine receptor densities (D-1 left, D-2 right) are present in the striatum and pallidum of the rat. B. (On facing page.) Sections through entopeduncular

al., '87). The number of D-1 and D-2 receptors was less than that seen in the rat (Table 2 ). The pattern of receptor distribution within the caudate, putamen, and nucleus accumbens was studied in detail in relationship to the pattern of AChE staining in both neonatal (Fig, 6) and adult cats (Fig. 7). The D-1 receptor was very heterogeneous in the P-0

nucleus and substantia nigra. Dopamine receptors (D-1 left, D-2 right) are heterogeneous in these structures. The entopeduncular nucleus contains only D-1 receptors, which are more prominent around the periphery and medial portions of the nucleus. The substantia nigra contains both D-1 and D-2 receptors in the pars reticulata and compacta with decreasing gradients from medial to lateral, Scale bar $=2 \mathrm{~mm}$.

kitten, becoming more homogeneous with maturity at P-7 and in the adult. The areas of increased D-1 receptor density in neonatal cats were seen on a diffuse background of lesser D-1 receptor binding. Areas of increased D-1 receptor density frequently corresponded to patches of increased $\mathrm{AChE}$ staining, having the same size, shape, contour, and 

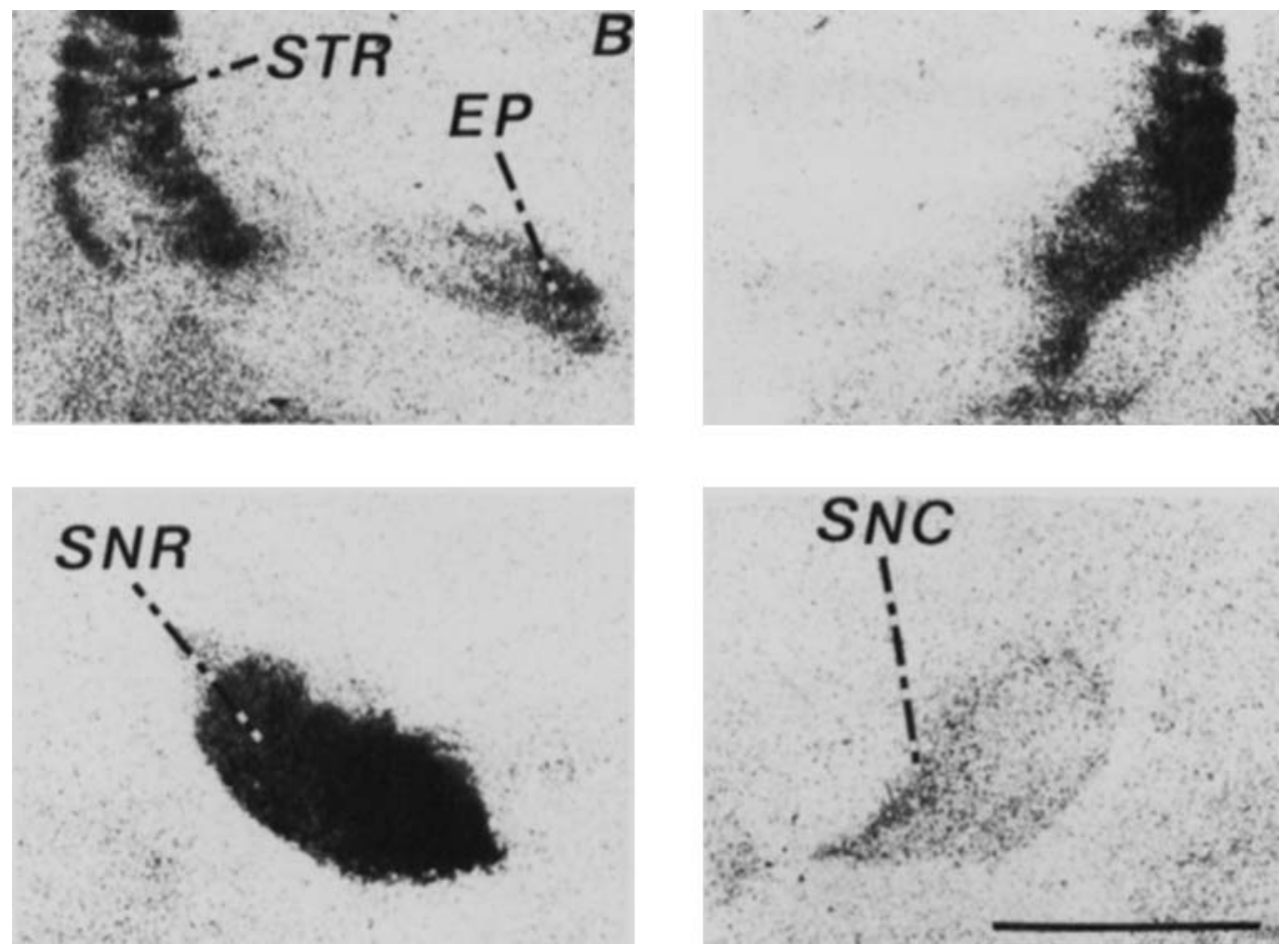

Figure 5 continued

distribution. The areas of increased D-1 receptor binding were seen most frequently in the caudate nuclei, but were also seen in the putamen, nucleus accumbens, and olfactory tubercle. The pattern of D-2 receptor binding was remarkable for its local homogeneity in all BG structures of the neonatal kitten, becoming mildly heterogeneous in the adult BG. There was a decreasing gradient from dorsal to ventral for both the $D-1$ and $D-2$ receptor density in the caudatc nucleus of the P-0 kitten, which decreased at age P-7 and disappeared in adults. No medial to lateral gradient for either receptor subtype was seen at any age. This was in contrast to the pattern seen with AChE staining in which there were decreasing gradients from lateral to medial and ventral to dorsal in the P-0 kitten, which was less marked in the P 7 kitten and absent in the adult cat.

The adult cat basal ganglia displayed a different appearance in receptor binding. Both the D-1 and D-2 receptor were more homogeneous when compared to the marked hetcrogeneity seen with AChE staining. However, local variations in the number of both $D-1$ and $D-2$ receptors on the order of $10-20 \%$ above or below the average binding were seen. The areas of variable density rarely corresponded to areas of low AChE staining (striosome). The areas of increased receptor binding had variable sizes from 0.8 to $2.0 \mathrm{~mm}$ in length, variable shapes from linear to oval or round, and irregular borders. In some sections, the areas of increased binding appeared to stretch from the medial to lateral aspect of the caudate nucleus. This appearance was different from the appearance of the striosomes, which were often tubular, linear, or angled, 0.3 to $0.5 \mathrm{~mm}$ in length, and had sharp contours. The striosomes were most prominent in areas of lower homogeneous receptor binding. Con. versely, the areas of increased receptor binding were more prominent in the matrix or area with homogeneous $\mathrm{AChE}$ staining. The areas of increased receptor binding could be traced on serial sections for up to 140 to $200 \mu \mathrm{M}$. On many occasions both D-1 and D-2 receptor binding were increased in the same pattern in adjacent sections. In other areas only one of the receptor subtypes was increased. Attempts were made to avoid artifactually finding heterogeneous binding by comparing serially adjacent sections (Fig. 8). Most autoradiographic sections were run in duplicate or triplicate and readings were made in areas verified on adjacent sections when possible. Areas of heterogeneity were also present in the putamen, nucleus accumbens, and olfactory tubercle.

The globus pallidus had a reticulated or lacelike pattern of binding for the D-2 receptor, with no detectable D-1 receptor binding. In the EP and SNR, D-1 receptor binding was high, whereas D-2 receptor binding (Fig. 9) was absent. The SNC contained both D-1 and D-2 receptors. The sub stantia nigra had a decreasing receptor gradient from medial to lateral for both D-1 and D-2 receptors. A district of increased D-1 and D-2 receptor binding was seen in the dorsomedial aspect of the nucleus accumbens.

\section{Dopamine receptor distribution in monkey}

Dopamine receptors were present in all nuclei of the adult monkey basal ganglia (Fig. 10), but in amounts less than for the rat and cat (Table 3). There were no right/left differences in the number of receptors for any of the structures examined. There was no medial to lateral or dorsal to ventral gradient for either receptor subtype in the caudate nuclei or putamen. There was a rostral to caudal gradient for both receptor subtypes, which was greater for the D-1 receptor. The D.1 receptor decreased by $9 \%$ in the body and $17 \%$ in the tail of the caudate nuclei, compared to the head of the nuclcus, whereas the caudal portion of the putamen decreased by $29 \%$ when compared to the rostral putamen. The D-2 receptor, however, increased by $15 \%$ in the body 

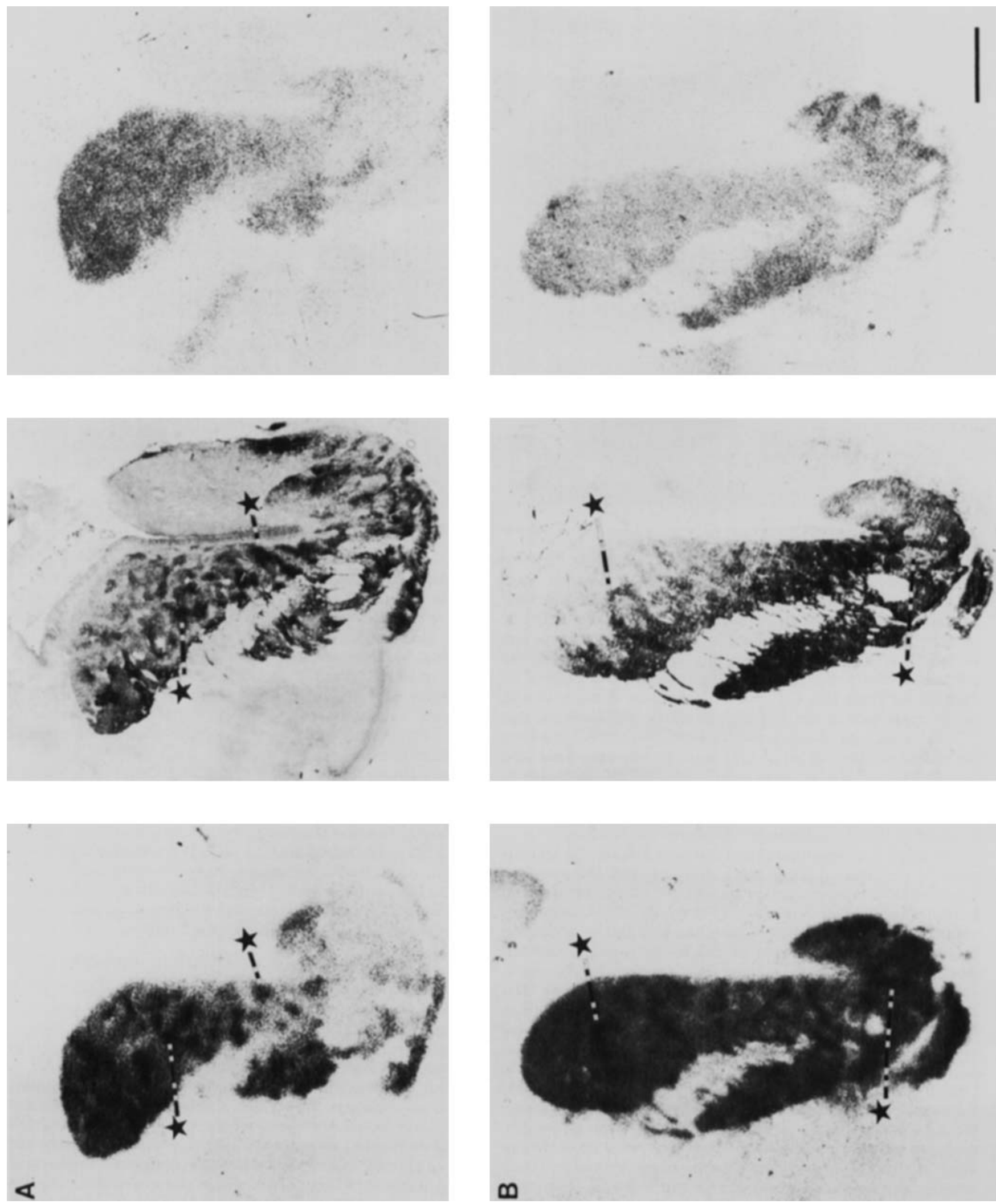
TABLE 2. Summary of Adult Cat Dopamine Receptor Distribution

\begin{tabular}{|c|c|c|c|c|c|c|}
\hline & \multicolumn{6}{|c|}{ Receptor subtypes } \\
\hline & \multicolumn{3}{|c|}{ D. 1} & \multicolumn{3}{|c|}{$\mathrm{D}-2$} \\
\hline & $\begin{array}{l}\text { Amount } \\
\text { bound } \\
\text { (pmol/mg } \\
\text { protein } \\
\pm \text { SD) } \\
\end{array}$ & $\begin{array}{l}\text { Amount } \\
\text { bound } \\
\text { relative to } \\
\text { rostral } \\
\text { caudate } \\
(\%)^{\mathrm{b}}\end{array}$ & $\begin{array}{c}\text { Amount } \\
\text { bound } \\
\text { relative } \\
\text { to total } \\
\text { dopamine } \\
\text { receptors } \\
(\%)^{\mathrm{c}}\end{array}$ & $\begin{array}{l}\text { Amount } \\
\text { bound } \\
\text { (pmol/mg) } \\
\text { protein } \\
\pm \mathrm{SD})^{\mathrm{a}}\end{array}$ & $\begin{array}{l}\text { Amount } \\
\text { bound } \\
\text { relative to } \\
\text { rostral } \\
\text { caudate } \\
(\%)^{\mathrm{b}}\end{array}$ & $\begin{array}{c}\text { Amount } \\
\text { bound } \\
\text { relative } \\
\text { to total } \\
\text { dopamine } \\
\text { receptors } \\
(\%)^{\circ}\end{array}$ \\
\hline \multicolumn{7}{|l|}{ Caudate (rostral) } \\
\hline Average $^{d}$ & $1.26 \pm 0.13$ & 100 & 72 & $0.50 \pm 0.05$ & 100 & 28 \\
\hline Highe $^{\mathrm{e}}$ & $1.39 \pm 0.17$ & 110 & 68 & $0.64 \pm 0.13$ & 128 & 32 \\
\hline Low" & $1.06 \pm 0.21$ & 84 & 76 & $0.33 \pm 0.03$ & 66 & 24 \\
\hline Caudate (cauda)) & $0.98 \pm 0.11$ & 78 & 68 & $0.47 \pm 0.09$ & 94 & 32 \\
\hline \multicolumn{7}{|l|}{ Putamen (rostral) } \\
\hline Average & $1.04 \pm 0.17$ & 83 & 66 & $0.53 \pm 0.07$ & 106 & 34 \\
\hline High & $1.21 \pm 0.15$ & 96 & 68 & $0.57 \pm 0.08$ & 114 & 32 \\
\hline Low & $0.89 \pm 0.11$ & 71 & 71 & $0.36 \pm 0.02$ & 72 & 29 \\
\hline Putamen (caudal) & $0.68 \pm 0.34$ & 54 & 68 & $0.32 \pm 0.04$ & 64 & 32 \\
\hline \multicolumn{7}{|l|}{ Nucleus accumbens (rostral) } \\
\hline Average & $0.71 \pm 0.29$ & 56 & 62 & $0.43 \pm 0.10$ & 86 & 38 \\
\hline High & $1.00 \pm 0.12$ & 79 & 64 & $0.57 \pm 0.07$ & 114 & 36 \\
\hline Low & $0.67 \pm 0.13$ & 53 & 66 & $0.35 \pm 0.02$ & 70 & 34 \\
\hline Nucleus accumbens (caudal) & $0.57 \pm 0.16$ & 45 & 68 & $0.27 \pm 0.02$ & 54 & 32 \\
\hline \multicolumn{7}{|l|}{ Olfactory tubcrcle } \\
\hline Average & $0.84 \pm 0.12$ & 67 & 72 & $0.32 \pm 0.10$ & 64 & 28 \\
\hline High & $1.06 \pm 0.15$ & 84 & 73 & $0.40 \pm 0.08$ & 80 & 27 \\
\hline Low & $0.63 \pm 0.04$ & 50 & 78 & $0.18 \pm 0.09$ & 36 & 22 \\
\hline Globus pallidus & ND & 0 & 0 & $0.22 \pm 0.01$ & 44 & 100 \\
\hline Entopenduncular nucleus & $0.82 \pm 0.05$ & 65 & 100 & ND & 0 & 0 \\
\hline \multicolumn{7}{|l|}{ Substantia nigra-compactid } \\
\hline Average & $0.72 \pm 0.01$ & 57 & 81 & $0.17 \pm 0.01$ & 34 & 19 \\
\hline Medial & $0.81 \pm 0.10$ & 64 & 79 & $0.21 \pm 0.02$ & 42 & 21 \\
\hline Lateral & $0.45 \pm 0.23$ & 36 & 87 & $0.07 \pm 0.04$ & 14 & 13 \\
\hline \multicolumn{7}{|l|}{ Substantia nigra-reticulata } \\
\hline Average & $0.72 \pm 0.08$ & 57 & 100 & ND & 0 & 0 \\
\hline Medial & $0.80 \pm 0.08$ & 63 & 100 & ND & 0 & 0 \\
\hline Lateral & $0.62 \pm 0.24$ & 49 & 100 & ND & 0 & 0 \\
\hline Claustrum & $0.30 \pm 0.04$ & 24 & 86 & $0.05 \pm 0.02$ & 10 & 14 \\
\hline
\end{tabular}

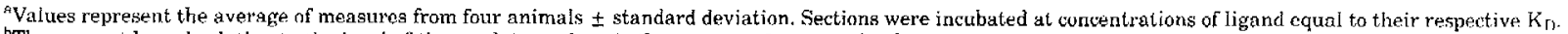
'The amount bound relative to the head of the caudate nucleus is the amount of receptor binding present in a region expressed as a percentage relative to the average amount

"The amount bound relative to the total number of dopamine receptors is the amount of dopamine receptor subtype present in a particular region expressed as a percentuge of the total number of D. 1 and 1$)-2$ receptors present in that region.

"The average amount of binding present. in a region represents the amount of binding present ignuring any heterogeneity of binding.

The high and low amounts of hinding represent the amount of binding present in a region visually selected for areas of increased or decreased binding relative to the average amount present.

$\mathrm{ND}$ : none detected.

and tail of the caudate compared to the head and the caudal putamen increased by $8 \%$ compared to the rostral putamen. The head of the caudate, rostral putamen, and $n$. accumbens displayed minimal amounts of heterogeneous binding. The pattern of binding for both the D-1 and D-2 receptors

Fig. 6. Dopamine receptor autoradiography and $\mathrm{AChE}$ staining in kitten BG. Dopamine receptor autoradiography was performed in adjacent section in P-0 and P47 kittens as described in the text and Figure 4. Adjacent sections were also processed for $\mathrm{AChE}$ staining. A. Sections through portions of the BG of a P.0 kitten. D-1 dopamine receptors (left) are quite heterogeneous with areas of increased recoptor density matehing areas of increased AChE staining (middle). The D-2 receptor distribution is quite homogeneous (left). Dopamine receptor gradients are present, with higher levels present dorsally. AChE gradients are also present, with higher levels laterally. B. Sections through portions of BG of a P-7 kitten. A similar pattern of binding and staining is seen in the P-7 kitten, exccpt that the gradients are decreased, and the intensity of the AChE staining in the matrix is increased. Sections are in the same order as in A. Scale bar $=2$ $\mathrm{mm}$. Asterisks indicate areas of $\Lambda \mathrm{ChE}$ rich patches and increased $\mathrm{D}-1$ receptor binding. did not match the "patchy" heterogeneity seen with AChE staining. Most areas of increased receptor density appeared to be present in the matrix region as seen by $\mathrm{AChE}$ staining. Areas of increased or decreased binding were on the order of $10-20 \%$ and were of variable size and shape. The caudal portions of the caudate nucleus and putamen were much more homogeneous than the rostral portions.

The pallidum demonstrated dopamine receptor binding in a pattern similar to that of the rat and cat. Medial GP ( $\mathrm{EP}$ in the rat and cat) had a moderate number of $\mathrm{D}-1$ receptors in a pattern of higher binding around the periphery, but lower amounts in the central portion of the nucleus and no detectable D-2 receptors. Lateral GP (GP in the rat and cat) had nearly equivalent but low numbers of D-1 and D-2 receptors without any heterogeneity to the binding. The substantia nigra pars compacta contained only D-2 receptors, whereas the pars reticulata contained only D-1 receptors in decreasing gradients from both medial to lat- 

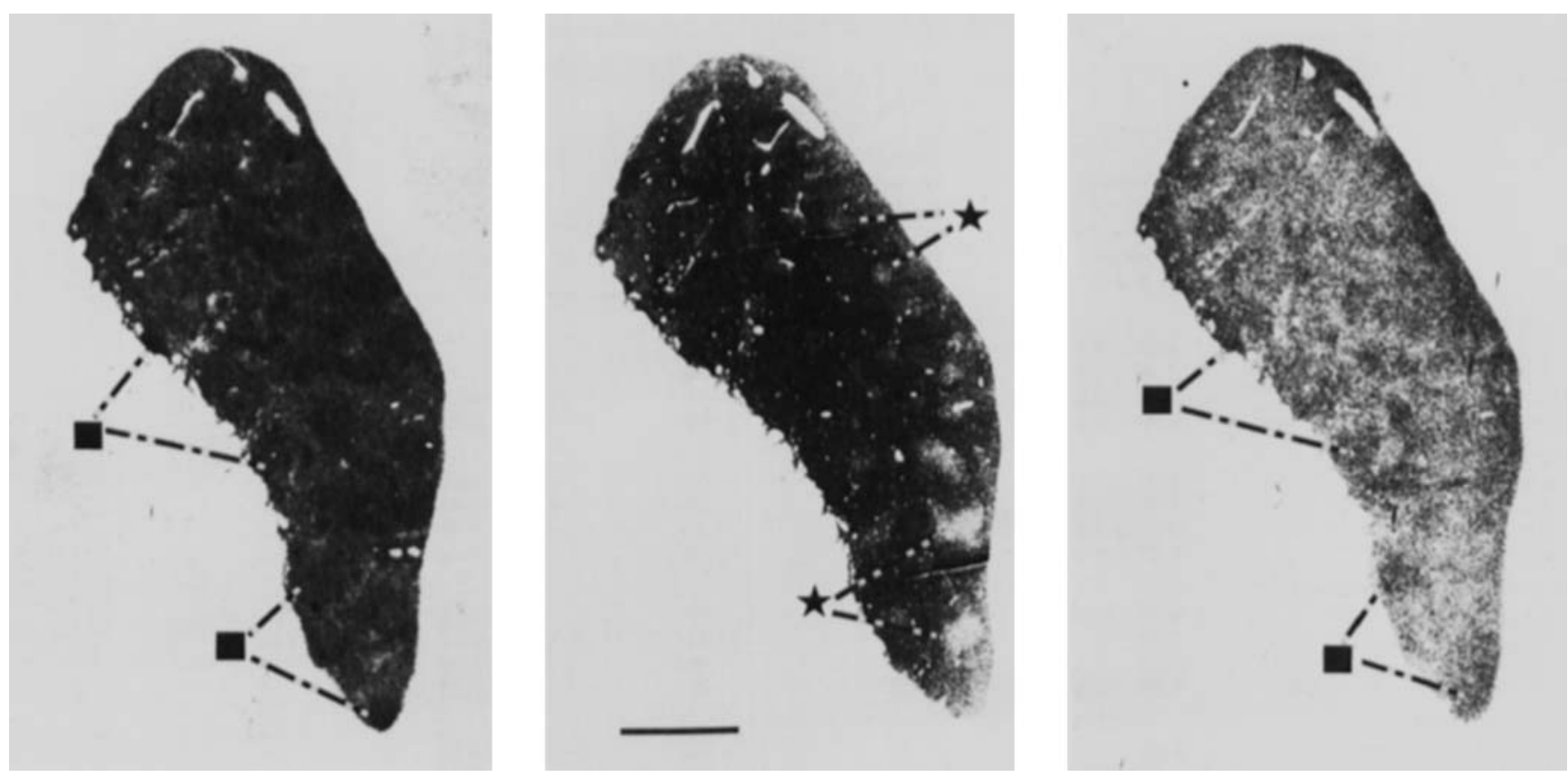

Fig. 7. Dopamine receptor autoradiography and AChE staining in the cat caudate nucleus. Dopamine receptor autoradiography was performed in adjacent sections as described in the text and Figure 4. Adjacent sections were processed for AChF staining. The distributions of both D-1 (left) and D-2 (right) receptors are heterogeneous in fashions that are different from that seen with $\mathrm{AChE}$ staining (middle). Some areas of striatum have in-

eral and ventral to dorsal. The SNR D-1 receptors also decreased from ventral to dorsal.

\section{DISCUSSION}

\section{Phylogenetic conservation of dopamine receptors}

The conservation of neuronal pathways and neurotransmitters among amniotes has been established (Reiner et al., '84). In this study, we found that the dorsal striatum, consisting of caudate nucleus and putamen, contained the greatest number of both D-1 and D-2 receptors in the mammals. The homologues of the dorsal striatum in the turtle (PA) and pigeon (PP and PA) also contained measurable amounts of D-1 and D-2 dopamine receptors. There were lesser amounts in the paleostriatum (globus pallidus) of all vertebrates examined. The ventral striatum (nucleus accumbens and olfactory tubercle) and claustrum also contained measurable amounts of D-1 and D-2 receptors in the mammals. In mammals, there were twice as many D-1 receptors as D-2 receptors in the striatum, whereas D-2 receptors exceeded D-1 receptors in the turtle and pigeon striatal homologues. This difference in density of dopamine receptor subtypes suggests that in different species these structures may react differently to dopamine. The mam mals also have a high percentage of D-1 receptors in the claustrum and substantia nigra pars reticulata. Although asymmetries in D-2 receptor binding in the striatum of male and female rats have been reported (Drew et al., '86), in this study no asymmetries were found in any structures examined in the rat or monkey for either receptor subtype.

\section{Mammalian differences in dopamine receptors}

There were differences in the distribution and density of both $\mathrm{D}-1$ and $\mathrm{D}-2$ receptors among the mammals studied. The density of D-1 and D-2 receptors was highest in the rat, creased levels of both D-1 and D-2 receptors; some areas are increased in only one subtype. The $\mathrm{AChE}$ staining reveals several striosomes that have no clear counterpart in the pattern of receptor binding. Scale bar $=2 \mathrm{~mm}$. Asterisks indicate striosomes with low AChE staining, and filled squares indicate areas of increased D-1 and D-2 receptor binding.

followed by the cat, then the monkey. When various basal ganglia structures were compared among the mammals, the cat contained from 45 to $86 \%$ and the monkey contained from 32 to $63 \%$ of the total number of dopamine receptors compared to the rat. This rank order for species was true for all structures of the basal ganglia examined. This pattern of decreasing total number of dopamine receptors among higher mammals is similar to the pattern of decreasing cerebral metabolic rates also seen with higher mammals (Sokoloff, '84). One may speculate as to whether the increased receptor numbers result in a higher metabolic demand on a neuron.

The mammals displayed differing densities of D-1 and D2 receptors in the paleostriatum and substantia nigra. The MGP contained moderate amounts of the D-1 receptor, varying from 24 to $65 \%$ of the number seen in the caudate nucleus without detectable D-2 receptor binding. The LGP contained far fewer numbers of D-1 receptors varying from none to $14 \%$ of the number seen in the caudate nucleus. However, low amounts of D-2 receptors were also present in the LGP. Thus, the pallidal subdivisions may process DA inputs differently. The SN also differed among the mammals in the distribution of dopamine receptors. The SNC of all mammals contained D-2 receptors, but only the rat and cat also had D-1 receptors in the SNC. The SNR of all mammals contained D-1 receptors, but only the rat also contained D-2 receptors in the SNR. These results suggest that mammals differ in their processing of information in these portions of the basal ganglia.

\section{Heterogeneities in dopamine receptor binding}

The mammals also differed in the local distribution of dopamine receptors within a region. Three types of heterogeneities were observed in the pattern of dopamine receptor 

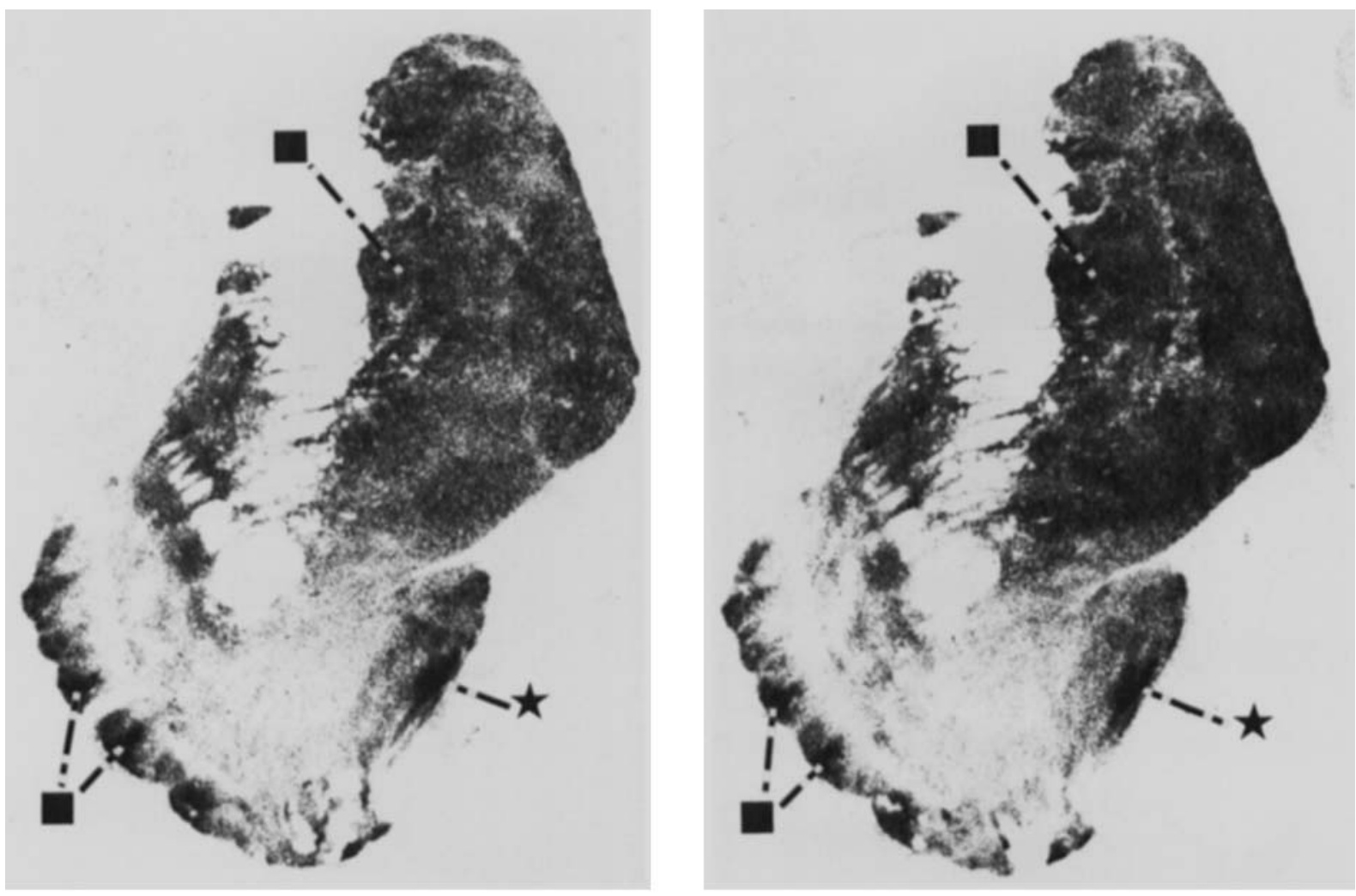

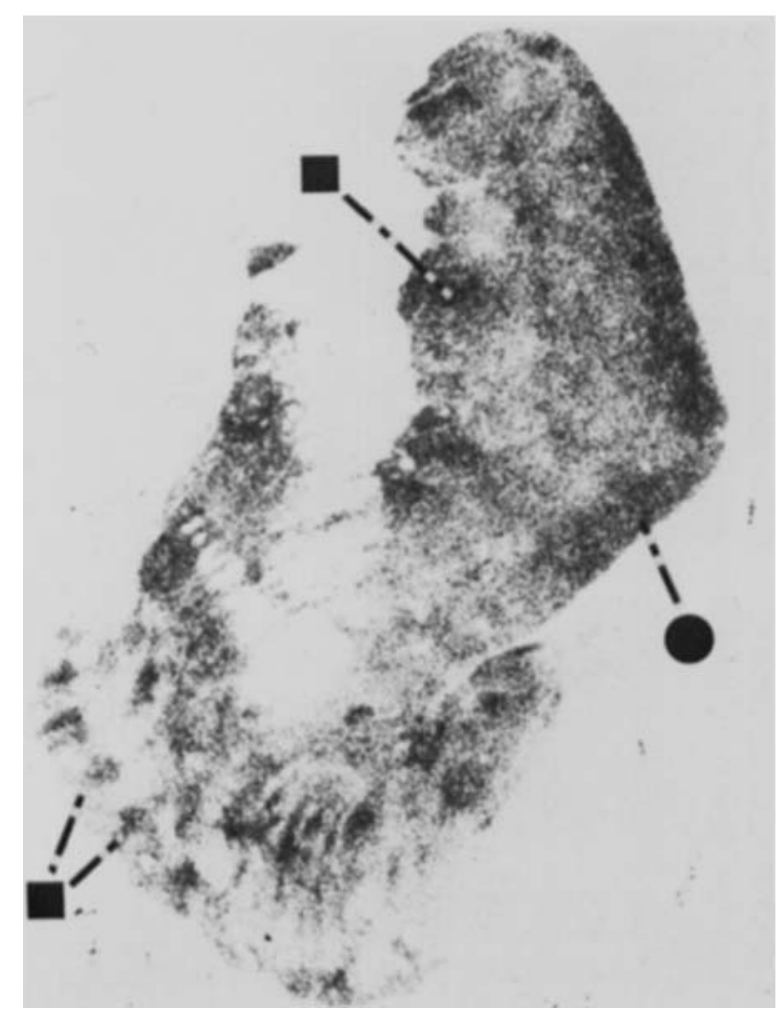

Fig. 8. Dopamine receptor autoradiography in adjacent sections of the cat brain. Four adjacent sections were processed for either D-1 (upper) or D2 (lower) dopamine receptor autoradiography. Matching of areas with increased D-1 or D-2 receptors can be seen on adjacent sections processed for the same receptor subtype. In addition, some areas with increased amounts of both D-1 and D-2 receptors can be seen to match. There are also some

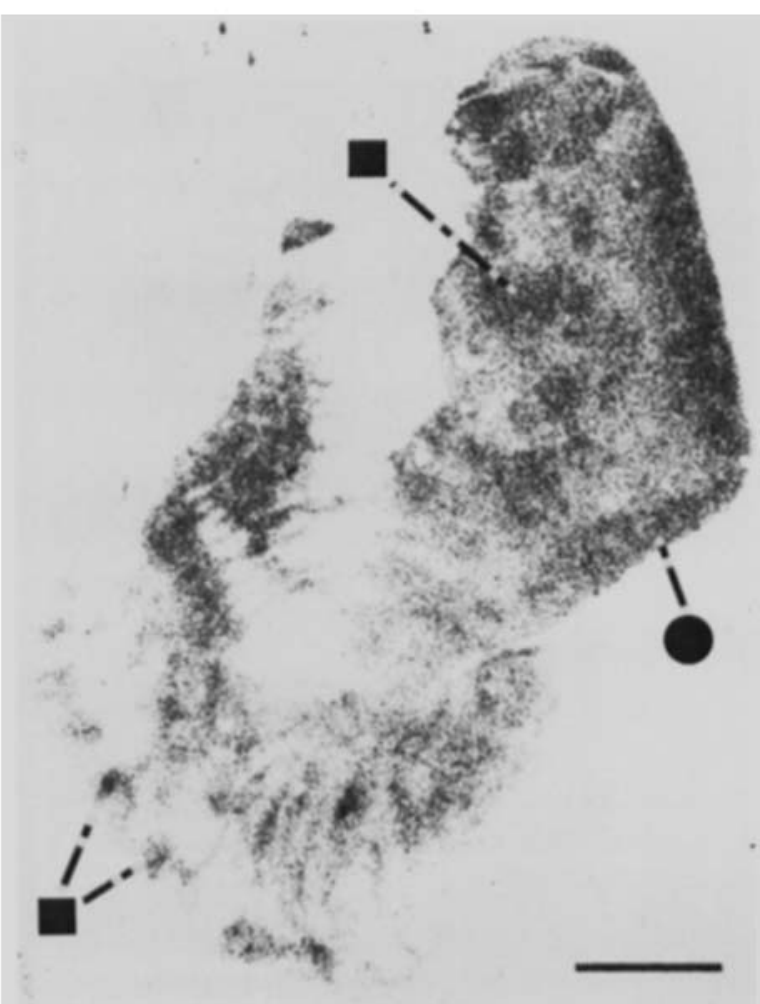

areas where increased receptor subtypes do not match. Areas of heterogeneity can be seen in the caudate nucleus, putamen, nucleus accumbens, and olfactory tubercle. Scale bar $=2 \mathrm{~mm}$. Filled squares indicate areas of increased D-1 and D-2 receptor hinding in adjacent sections. Asterisk indicates an area with increased D-1, but not D-2 receptor binding. Filled circle indicates an area of increased D-2, but not D-1 receptor hinding. 

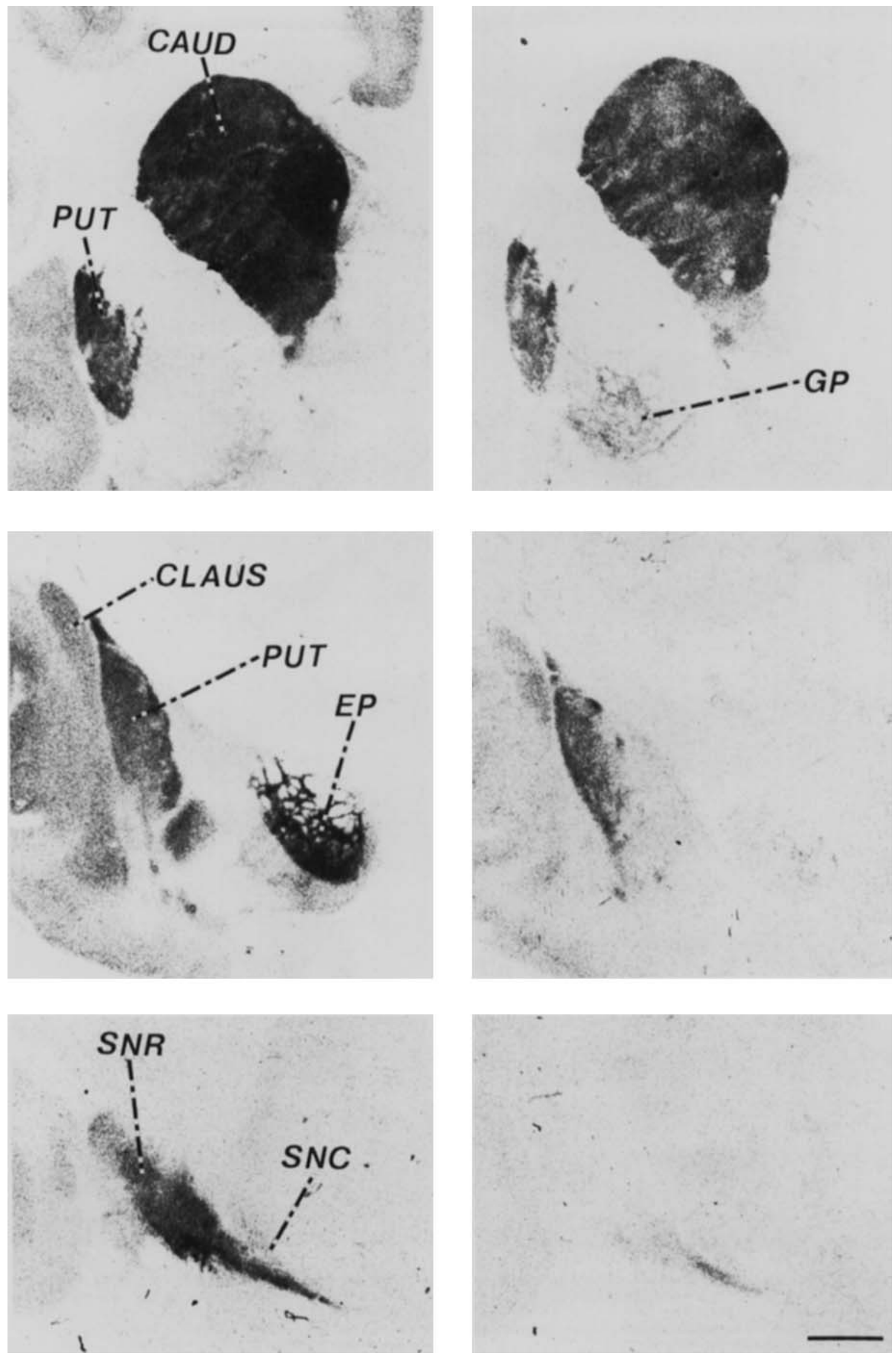
TABLE 3. Summary of Monkey Dopamine Receptor Distribution

\begin{tabular}{|c|c|c|c|c|c|c|}
\hline & \multicolumn{6}{|c|}{ Receptor subtypes } \\
\hline & \multicolumn{3}{|c|}{ D-1 } & \multicolumn{3}{|c|}{$\mathrm{D}-2$} \\
\hline & $\begin{array}{l}\text { Amount } \\
\text { bound } \\
\text { (pmol/mg } \\
\text { protein } \\
\pm S D)^{4}\end{array}$ & $\begin{array}{l}\text { Amount } \\
\text { bound } \\
\text { relative to } \\
\text { midstriatum } \\
(\%)^{\mathrm{b}}\end{array}$ & $\begin{array}{c}\text { Amount } \\
\text { bound } \\
\text { relative } \\
\text { to total } \\
\text { dopamine } \\
\text { receptors } \\
(\%)^{c} \\
\end{array}$ & $\begin{array}{c}\text { Amount } \\
\text { bound } \\
\text { (pmol/mg) } \\
\text { protein } \\
\pm \mathrm{SD})^{3} \\
\end{array}$ & $\begin{array}{c}\text { Amount } \\
\text { bound } \\
\text { relative } \\
\text { to head } \\
\text { of caudate } \\
(\%)^{b}\end{array}$ & $\begin{array}{l}\text { Amount } \\
\text { bound } \\
\text { relative } \\
\text { to total } \\
\text { dopamine } \\
\text { receptors } \\
(\%)^{c} \\
\end{array}$ \\
\hline \multicolumn{7}{|l|}{ Caudate (head) } \\
\hline Averaged & $0.98 \pm 0.06$ & 100 & 72 & $0.39 \pm 0.07$ & 100 & 18 \\
\hline Highe $^{e}$ & $1.12 \pm 0.06$ & 114 & 65 & $0.60 \pm 0.17$ & 154 & 35 \\
\hline Low ${ }^{\mathrm{e}}$ & $0.76 \pm 0.07$ & 78 & 70 & $0.32 \pm 0.06$ & 82 & 30 \\
\hline Caudate (body) & $0.89 \pm 0.09$ & 92 & 66 & $0.45 \pm 0.07$ & 115 & 34 \\
\hline Caudate (tail) & $0.81 \pm 0.10$ & 83 & 64 & $0.45 \pm 0.11$ & 115 & 36 \\
\hline \multicolumn{7}{|l|}{ Putamen (rostral) } \\
\hline Average & $0.90 \pm 0.09$ & 92 & 71 & $0.36 \pm 0.02$ & 92 & 29 \\
\hline High & $0.96 \pm 0.08$ & 98 & 63 & $0.56 \pm 0.13$ & 114 & 37 \\
\hline Low & $0.73 \pm 0.10$ & 74 & 70 & $0.32 \pm 0.03$ & 82 & 30 \\
\hline Putamen (caudal) & $0.64 \pm 0.04$ & 65 & 62 & $0.39 \pm 0.04$ & 100 & 38 \\
\hline \multicolumn{7}{|l|}{ Nucleus accumbens } \\
\hline Average & $0.58 \pm 0.04$ & 59 & 74 & $0.20 \pm 0.04$ & 51 & 26 \\
\hline High & $0.65+0.04$ & 66 & 63 & $0.38 \pm 0.03$ & 97 & 37 \\
\hline Low & $0.5^{\circ} \pm 0.02$ & 53 & 78 & $0.15 \pm 0.03$ & 38 & 22 \\
\hline Lat. globus pallidus & $0.04 \pm 0.01$ & 4 & 57 & $0.03+0.01$ & 8 & 43 \\
\hline Med. globus pallidus & $0.24 \pm 0.01$ & 24 & 100 & ND & 0 & 0 \\
\hline \multicolumn{7}{|c|}{ Substantia nigra-compacta } \\
\hline Average & ND & 0 & 0 & $0.15 \pm 0.05$ & 38 & 100 \\
\hline \multicolumn{7}{|c|}{ Substantia nigra-reticulata } \\
\hline Average & $0.44 \pm 0.07$ & 45 & 100 & ND & 0 & 0 \\
\hline Medial & $0.51 \perp 0.06$ & 52 & 100 & ND & 0 & 0 \\
\hline Lateral & $0.35 \perp 0.03$ & 36 & 100 & $\mathrm{NI}$ & 0 & 0 \\
\hline Ventral & $0.53 \pm 0.04$ & 54 & 100 & $\mathrm{ND}$ & 0 & 0 \\
\hline Dorsal & $0.39 \pm 0.02$ & 40 & 100 & ND & 0 & 0 \\
\hline Claustrum & $0.19 \pm 0.06$ & 19 & 83 & $0.04 \pm 0.03$ & 10 & 17 \\
\hline
\end{tabular}

avalues represent the average of measures from four animals I standard deviation. Sections were incubated at concentrations of ligand equal to their respective $\mathrm{K}_{\mathrm{I}}$.

'The amount bound relative to the head of the caudate nucleus is the amount of receptor binding present in a region expressed as a percentage relative to the average amount present in the head of the cuadule.

"I'he amount bound relative to the total number of dopamine receptors is the amount of dopamine receptor subtype present in a particular region expressed as a percentage of the total number of D-1 and D-2 receptors present in that region.

${ }^{\mathrm{d}}$ The average amount of binding prosent in a region represents the amount of binding present ignoring any heterogeneity of hinding

"The high and low amounts of binding represent the amount of binding preserit in a region visually selected for areas of increased or decreased hinding relative to the average amounl present

ND = none detected.

binding in the basal ganglia of mammals. Gradients, defined as an increase or decrease in receptor density or marker intensity following one axis, have been described for various basal ganglia markers in the past (Bockaert et al., '76; Tassin et al., '76; Versteeg et al., '76). Patches are scattered arcas of increased or decreased marker within a region or background (matrix) of homogeneous marker. These have also been well described in mammalian basal ganglia (Graybiel, '81a,b; Graybiel et al., '84; Gerfen, '85,'86). A district is defined as a portion of a region that has a unique pattern of binding or labeling that distinguishes it from the remainder of the region, but may not be distinguishable on routine histologic staining. These have also been described in portions of the basal ganglia (Graybiel et al., ' 81 a). The types of dopamine receptor heterogene-

Fig. 9. Dopamine receptor autoradiography in portions of the cat BG. Dopamine receptor autoradiography was performed in regions of the cat $\mathrm{BG}$, including globus pallidus (upper), entopeduncular nucleus (middle), and substantia nigra (lower). Dopamine D-1 receptors (left) are present in the $\mathrm{EP}, \mathrm{SNC}$, and SNR; D-2 receptors are present in GP and SNC. The SN has a decreasing medial to lateral gradient as is seen in the rat. Scale bar $=2$ $\mathrm{mm}$. ities varied among the mammals examined, regions of the basal ganglia, and receptor subtype.

Considerable interest has been generated regarding the patchy heterogeneities seen in mammals, especially cats, monkeys, and humans. Patches are seen in the prenatal brain that persist in adulthood, but may change in their neurochemical attributes. This type of heterogeneity is classically detected by using AChE staining, but has been noted with other markers (Graybiel and Ragsdale, '78). Dopamine also demonstrates heterogeneity in prenatal brains where it is localized to "islands" or patches of increased amounts surrounded by a matrix or background of lesser amounts (Olson et al., '72; Graybiel, '84). The matrix area increases in dopamine content with maturity until striatal dopamine becomes homogeneous in adulthood. The distribution patterns of the D-1 and D-2 receptors in adults were distinctly different from this pattern and from each other. Whereas the D-1 receptor had patches of increased receptor binding that corresponded to patches of increased AChE staining during development, the changes in the receptor with maturity differed from those of AChE staining and dopamine markers. In the dorsal striatum, AChE staining and dopamine histofluorescence in the matrix increased with maturation; the $\mathrm{D}-1$ receptor density de- 

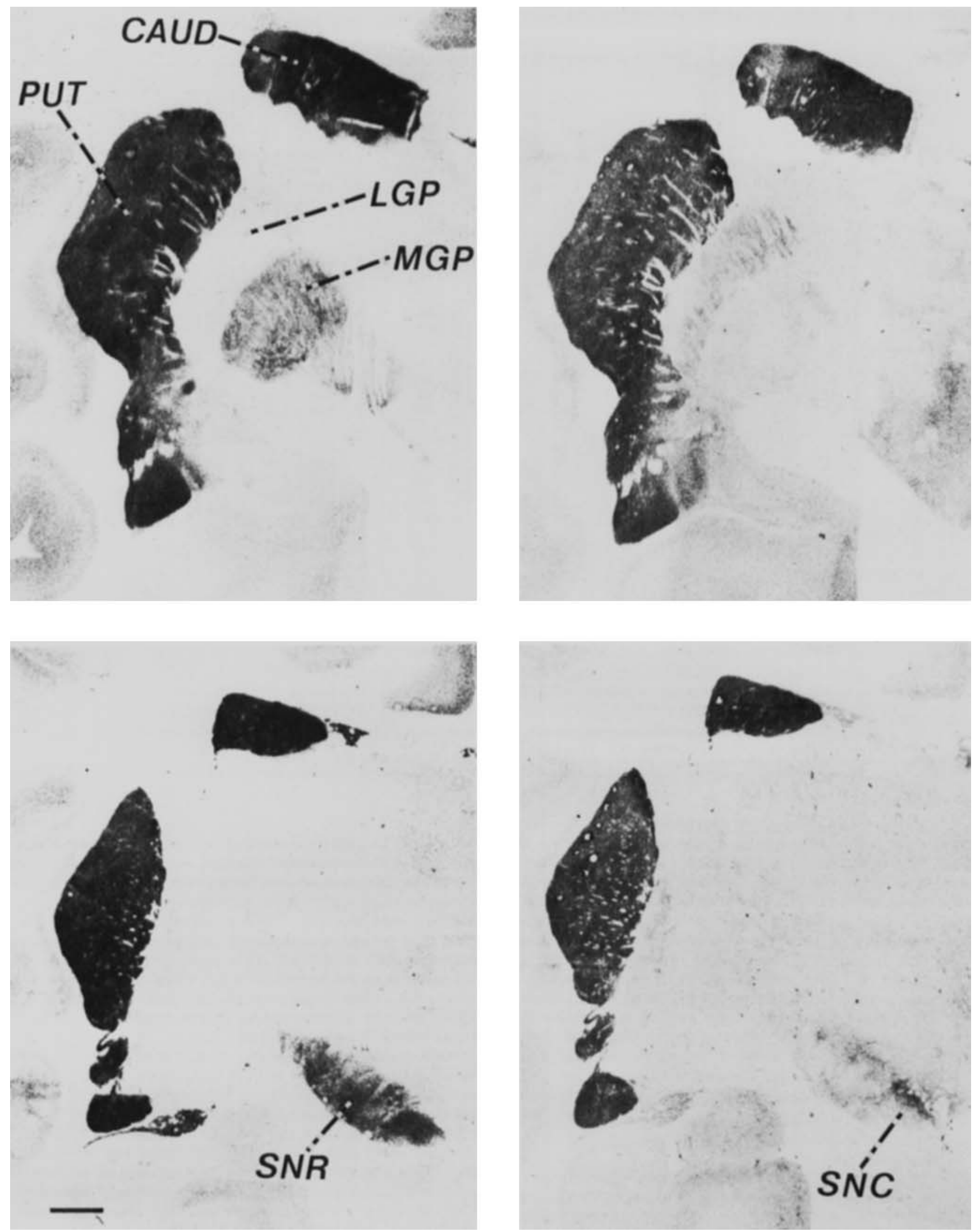

Fig. 10. Dopamine receptor autoradiography of the monkey BG. Dopamine receptor autoradiography was performed in adjacent sections from regions of the monkey BG. Dopamine D-1 receptors (left) are present in caudate nucleus, putamen, LGP, MGP, and SNR; D.2 receptors (right) are present in caudate nucleus, putamen, LGP, and SNC. Heterogeneities can be seen in the striatum and SN. Scale bar $=2 \mathrm{~mm}$. 
creases with maturation (Richfield et al., '87). Whereas part of this decrease in receptor density may be an artifact attributable to increasing lipid content in the striatum, it is remarkable how many receptors were present at this early age. The D-1 receptor in the adult was heterogeneous, but the pattern was unlike AChE staining and dopamine histofluorescence.

The D-2 receptor was quite homogeneous in the neonate, unlike the D-1 receptor, AChE staining, and dopamine histofluorescence. The $\mathrm{D}-2$ receptor changed little in the aver age amount of binding with maturation in the dorsal striatum, but did become heterogeneous. The pattern of adult D-2 receptor heterogeneity did not match the adult pattern of AChE staining or dopamine histofluorescence, but did partially match the D-1 receptor pattern in that some areas show increased or decreased levels of both receptor subtypes. There were also mismatches between dopamine receptors, dopamine levels, and AChE staining in their respective gradients. These results suggest that complex developmental changes may occur independently among dopamine, dopamine receptor subtypes, and other neurochemical markers in the basal ganglia.

The adult cat demonstrated heterogeneous binding for both D-1 and D-2 receptors. Since AChE staining and immunocytochemistry are nonquantitative, it was not possible to relate the magnitude of heterogeneity in receptor binding to other measures of heterogeneity. Receptor heterogeneities were most frequently seen in the caudate nucleus, but were also seen in the $\mathrm{n}$. accumbens and olfactory tubercle. They were seldom seen in the putamen. This regional pattern of heterogeneity is very similar to the distribution seen with other markers. Since the total area of the matrix region identified by $\mathrm{AChE}$ staining exceeded the area of the striosomes, it appeared that receptor binding areas with increased density were more commonly seen in the matrix region. These receptor changes may also corre spond to the mosaic architecture of the somatic sensoryrecipient sector of the cat's striatum present within the extrastriosomal matrix (Malach and Graybiel, '86).

The distribution of dopamine receptors most clearly fits with that described for substance $\mathbf{P}$ immunoreactivity. The distribution of substance $P$ has been described as having areas of increased and decreased staining, which are "often thin, elongated, and tend to make a filigree pattern," and in general do not have an exact correspondence to $\mathrm{AChE}$ staining or enkephalin immunoreactivity (Graybiel et al., '81a). Whether dopamine receptor heterogeneities match substance $P$ immunoreactivity heterogeneities remains to be proven, but together these studies suggest an additional compartmentation of the caudate nucleus separate from the AChE-opiate compartmentation.

The heterogeneous distribution of dopamine receptors in the caudate and putamen also resembled the terminal field projections from various areas of cortex as described by Selmon and Goldman-Rakic (86). They reported that corticostriatal projections from association cortices terminate in longitudinal domains having restricted medial-lateral sectors. They speculated that these terminal fields would produce spatially distinct centers of excitation.

Quantification of receptor density with autoradiography suffers from the potential error of weak $\beta$ particle absorption by lipids (Kuhar et al., '86; Herkenham and Sokoloff, '84; Geary et al., '85). This effect is most prominent in areas with variable or large amounts of white matter relative to the amount of white matter used in the brain tissue to calibrate standards. Thus, absolute values cannot be deter- mined without other modifications of this technique, such as lipid extraction (Herkenham and Sokoloff, '84; Geary et al., '85) or the use of ${ }^{14} \mathrm{C}$ or ${ }^{125}$ I labeled ligands (Kuhar et al., '86). The variable density of white matter fibers also affects the quantification of any neurochemical marker that is determined on the basis of tissue weight or amount of protein. Thus, in structures with regionally variable amounts of lipid or protein, only general trends in measurements can be made. With this in mind, in rats the rostral to caudal decrease in receptor density paralleled the decrease seen in dopamine levels (Bockaert et al., '76; 'Tassin et al., '76). The cat had a similar gradient in the caudate and putamen. The monkey, however, showed a minimal or no rostral to caudal change in the D-2 receptor, and a slight decrease in the $D-1$ receptor.

\section{Cellular localization of dopamine receptors}

The cellular localization of dopamine receptor subtypes in different portions of the BG remains controversial. Dopamine D.2 receptors are thought to be present on cell bodies in the SNC and to be presynaptic and postsynaptic in the striatum (Moore and Bloom, '78; Creese et al., ' 83 ; Stoof and Kebabian, '84). Recent studies suggest that the D-2 receptor may be only postsynaptic in the rat striatum (Trugman et al., ' 86 ; Joyce et al., '86). The D-1 receptor has been found to be present on postsynaptic cells in the striatum and on presynaptic terminals in the SNR (Dubois et al., '86). The current study did not specifically address the cellular location of dopamine receptor subtypes. However, the finding that D-1 receptors in substantia nigra decreased after striatal lesions suggests that D-1 receptors may be associated with specific striatal projections (Altar et al., ' 86 ; Wamsley et al., ' 86 ). In this regard, it will be of interest to compare the distribution of D-1 receptors with that of substance $P$. High levels of substance $P$ immunoreactivity have been found in the medial GP, but not lateral GP of humans (Graybiel, '84), and in the SNR of rats with a decreasing medial to lateral gradient (Dr. Anton Reiner, personal communication). This pattern is similar to the pattern seen with $\mathrm{D}-1$ receptor binding. Striatal axons to GP, EP, and SN have been shown to come from separate cell populations (Beckstead and Cruz, '86). If D-1 receptors are presynaptic on substance $P$ afferents to MGP and SNR, it would be interesting to speculate that the D-2 receptor might be presynaptic on enkephalinergic afferents to LGP.

Different types of heterogeneities were seen in all three of the mammals studied, were seen for both the D-1 and D2 receptor, and were seen in most regions of the basal ganglia examined, including caudate nucleus, putamen, $\mathbf{n}$. accumbens, olfactory tubercle, pallidum, and substantia nigra. The frequency and diversity with which they were seen suggests that heterogeneous processing of information is common with the dopamine system within the basal ganglia. This is in contrast to the pattern seen in other regions of the cerebrum, which are much more homogeneous (E.K. Richfield, unpublished observation).

\section{ACKNOWLEIGMENTS}

We would like to thank Dr. Anton Reiner for providing the turtle and pigeon sections, as well as helpful anatomical discussions. We would also like to thank Dr. George Dauth for providing monkey tissue sections; Darrel Debowey for photographic assistance; and Genell Fries for secretarial assistance. This work was supported in part by the Tourette Syndrome Association (Bayside, NY) and USPHS grant NS 19613. 


\section{LITERATURE CITED}

Altar, C.A., K. Hauser, and M.R. Marien (1986) [ $\left.{ }^{125} \mathrm{I}\right] \mathrm{SCH} 23982$ autoradiog raphy reveals topography of nigral innervation by D-1 receptor-contain ing striatal neurons. Proc. Soc. Neurosci, 12:192 (abstract).

Altar, C.A., S. O'Neil, R.J. Walter, and J.F. Marshall (1985) Dopamine and serotonin receptor sites revealed by digital subtraction autoradiography. Science 228:597-600.

Anden, N.-E., A. Carlsson, A. Dahlström, K. Fuxe, N.A. Hillarp, and K. Larsson (1964) Demonstration and mapping out of nigro-neostriatal dopamine neurons. Life Sci. 3:523-530.

Anden, N.-E., A. Dahlström, K. Fuxe, K. Larsson, L. Olson, and U. Ungerstedt (1966) Ascending monoamine neurons to the telencephalon and diencephalon. Acta. Physiol. Scand. 67:313-326.

Beckstead, R.M., and C.J. Cruz (1986) Striatal axons to the globus pallidus, entopeduncular nucleus and substantia nigra come mainly from separate cell populations in cat. Neurosci. 19:147-158.

Beckstead, R.M., V.B. Domesick, and W.J.H. Nauta (1979) Efferent connections of the substantia nigra and ventral tegmental area in the rat Brain Res. 175:191-217.

Billard, W., V. Ruperto, G. Crosby, L.C. Iorio, and A. Barnett (1984) Characterization of the binding of ${ }^{3}{ }^{3} \mathrm{H}-\mathrm{SCH} 23390$, a selective $\mathrm{D}-1$ receptor antagonist ligand, in rat striatum. Life Sci. 35:885-893.

Bockaert, J, J. Premont, J. Glowinsky, A.M. Thierry, and J.P. Tassin (1976) Topographic distribution of dopaminergic innervation and of dopami nergic receptors in the rat striatum. II. Distribution and characteristics of dopamine, adenylate cyclase-interaction of D-LSD with dopaminergic receptors. Brain Res, 107:303-315.

Bylund, D.B. (1980) Analysis of receptor binding data. In Short Course Syllabus: Receptor Binding Techniques. Bethesda, MD: Society for Neuroscience, pp. 70-99.

Carlson, J.H., D.A. Bergstrom, and J.R. Walters (1986) Concurrent stimulation of D-1 and D-2 dopamine receptors appears necessary for full expression of posisynaptic effects of dopamine agonists in the basal ganglia. Proc Soc. Neurosci. 12:487 (abstract)

Carpenter, M.B., and P. Peter (1968) Nigrostriatal and nigrothalamic fibers in the rhesus monkey. J. Comp. Neurol. 144:93-116.

Cheng, Y.C., and W.H. Prusoff (1983) Relationship between the inhibition constant $\left(K_{1}\right)$ and the concentration of inhibition which causes fifty percent inhibition of an enzymatic reaction. Biochem. Pharm. Pharmacol. 22:3099-3108.

Creese, I., M.W. Hamblin, S.E. Leff, and D.R. Sibley (1983) The classifica tion of dopamine receptors: Relationship to radioligand binding. Ann. Rev. Neurosci. 6:43-57.

Dahlström, A., and K. Fuxe (1964) Evidence for the existence of monoamine containing neurons in the central nervous system. 1. Demonstration of monoamines in the cell bodies of brain stem neurons. Acta. Physiol. Scand. 62 [suppl. 232]:1-55.

Dawson, T.M., D.R. Gehlert, R.T. McCabe, A. Barnett, and J.K. Wamsley (1986) D-1 dopamine receptors in the rat brain: A quantitative autoradiographic analysis. J. Neurosci. 6:2352-2365.

Dawson, T.M., D.R. Gehlert, H.I. Yamamura, A. Barnett, and J.K. Wamsley (1985) D-I dopamine receptors in the rat brain: Autoradiographic local ization. Eur. J. Pharm. 108:323-325.

Donoghue, J.P., and M. Herkenham (1986) Neostriatal projections from individual cortical fields conform to histochemically distinct striata compartments in the rat. Brain Res. 365:397-403.

Drew, K.L., R.A. Iyon, M. Titeler, and S.D. Glick (1986) Asymmetry in D-2 binding in female rat striata. Brain Res. 363:192-195.

Dubois, A., M. Savasta, O. Curet, and B. Scatton (1986) Autoradiographic distribution of the D-1 agonist [ $\left.{ }^{3} \mathrm{H}\right] \mathrm{SKF} 38393$, in the rat brain and spinal cord. Comparison with the distribution of D-2 dopamine receptors, Neurosci, 19:125-137.

Fallon, J.H., and R.Y. Moore (1978) Catecholamine innervation of the basal forebrain IV. Topography of the dopamine projection to the basal fore brain and neostriatum. I. Comp. Neurol. 180:545-580.

Geary, W.A.III, A.W. Toga, G.F. Wooten (1985) Quantitative film autoradiography for tritium: Methodological considerations. Brain Res. 337:99108.

Geneser-Jensen, F.A., and T:W. Blackstad (1971) Distribution of acetyl cholinesterase in the hippocampal region of the guinea pig. I. Entorhi nal area, parasubiculum and presubiculum. Z. Zellforsch 144:460-481.

Gerfen, C.R. (1984) The neostriatal mosaic: Compartmentalization of corti costriatal input and striato-nigral output systems. Nature 311:461-463.

Gerfen, C.R. (1985) The neostriatal mosaic I. Compartmental organization of projections from the striatum to the substantia nigra in the rat. J. Comp. Neurol, 236:454-476.

Gershanik, O., R.E. Heikkila, and R.C. Duvoisin (1983) Behavioral correlations of dopamine receptor activation. Neurology 33:1489-1492.

Goldman-Rakic, P.S. (1981) Prenatal formation of cortical input and development of cytoarchitectonic compartments in the neostriatum of the rhesus monkey. J. Neurosci. 1:721-735.

Goldman-Rakic, P.S. (1982) Cytoarchitectonic heterogeneity of the primate neostriatum: Subdivision into island and matrix compartments. J. Comp. Neurol, 205;398-413.

Graybiel, A.M. (1984) Correspondence between the dopamine islands and striosomes of the mammalian striatum. Neurosci. 13:1157-1187.

Graybicl, A.M. and C.W. Ragsdale Jr (1978) Histochemically distinct com partments in the striatum of human, monkey, and cat demonstrated by acetylthiocholinesterase staining. PNAS 75:5723-5726.

Graybiel, A.M., C.W. Ragsdale Jr., E.S. Yoneoka, and R.P. Eide (1981a) An , immunohistochemical study of enkephalins and other neuropeptides in the striatum of the cat with evidence that opiate peptides are arranged to form mosaic patterns in register with the striosomal compartments visible by acetylcholinesterase staining. Neurosci, 6:377-397.

Graybiel, A.M., V.M. Pickel, T.H. Joh, D.J. Reis, and C.W. Ragsdale Jr. (1981b) Direct domonstration of a correspondence between the dopamine islands and acetylthiocholinesterase patches in the developing striatum. PNAS 78:5871-5875.

Herkenham, M., and S. McLean (1986) Mismatches between receptor and transmitter localizations in the brain. In C.A. Boast, E.W. Snowhill, and C.A. Altar (cds): Quantitative Receptor Autoradiography. New York. Alan R. Liss, Inc.

Herkenham, M., and C.B. Pert (1981) Mosaic distribution of opiate receptors, parafasicular projections and acetylcholinesterase in rat striatum. Nature 291:415-418.

Herkenham, M., and L. Sokoloff (1984) Quantitative receptor autoradiogra phy: Tissue defatting eliminates differential self-absorption of tritium radiation in gray and white matter of brain. Brain Res. 321:363-368.

Hess, E.S., G. Battaglia, A.B. Norman, L.C. Iorio, and I. Creese (1986) Guanine nucleotide regulation of agonist interactions at $\left[{ }^{3} \mathrm{H}\right] \mathrm{SCH} 23390$ labeled D-1 dopamine receptors in rat striatum, Eur. J. of Pharmacol. $121: 31-38$.

Hortnagel, H., F. Schlogl, G. Sperk, and O. Hornykiewicz (1983) The topographical distribution of the monoamine innervation in the basal gan glia of the human brain. In J.P. Changeux, P. Glowinski, M. Imbert, and F.E. Bloom (eds): Molecular and Cellular Interactions Underlying Higher Brain Functions, Progress in Brain Research, vol. 58. New York: Elsevier.

Jastrow, T.R., E.K. Richfield, and M.E. Gnegy (1984) Quantitative autoradiography of $\left[{ }^{3} \mathrm{H}\right.$-sulpiride binding sites in rat brain. Neurosci. Lett. 51:47-53.

Joyce, J.N, S.K. Loeschen, and J.F. Marshall (1985) Dopamine D-2 receptors in rat caudate-putamen: The lateral to medial gradient does not correspond to dopaminergic innervation. Brain Res. 338:209-218.

Karten, H.J., and W. Hodos (1967) A Stereotaxic Atlas of the Brain of the Pigeon (Columba Livia). Baltimore: The Johns Hopkins Press.

Kuhar, M.J., E.B. De Souza, and J.R. Unnerstall (1986) Neurotransmitter receptor mapping by autoradiography and other methods. Ann. Rev. Neurosci. $9+27-59$.

Lindvall, O., and A. Björklund A, (1979) Dopaminergic innervation of the globus pallidus by collaterals from the nigrostriatal pathway. Brain Res. 172:169-173.

Malach, R., and A.M. Graybiel (1986) Mosaic architecture of the somatic sensory-recipient sector of the cat's striatum. J. Neurosci. 6:3436-3458.

Nastuk, M.A., and A.M. Graybiel (1985) Patterns of muscarinic cholinergic binding in the striatum and their relation to dopamine islands and striosomes. J. Comp. Neurol. 237:176-194.

Neve K.A., A. Altar, C.A. Wong, and J.F, Marshall (1984) Quantitative analysis of $\left[{ }^{3} \mathrm{H}\right]$ spiroperidol binding to rat forebrain sections: Plasticity of neostriatal dopamine receptors after nigrostriatal injury. Brain Res 302:9-18.

Nock, B., G. Sedvall, B.S. McEwen (1986) Quantitative autoradiography of ['H]piquindone binding sites (dopamine $\mathrm{D}-2$ receptors) in rat brain. Eur J. of Pharm. 121:387-393.

Olson, L., A. Seiger, and K. Fuxe (1972) Heterogeneity of striatal and limbic innervation: Highly fluorescent islands in developing and adult rats Brain Res. 44:283-288.

Palacios, J.M., D.L. Niehoff, and M.H. Kuhar (1981) $\left[{ }^{3} \mathrm{H}\right]$ Spiperone binding sites in brain: Autoradiographic localization of multiple receptors. Brain 
Res. 213:277-289.

Pan, H.S., K.A. Frey, A.B. Young, and J.B. Penney (1983) Changes in ${ }^{3} \mathrm{H} /$ muscimol binding in substantia nigra, entopeduncular nucleus, globus pallidus and thalamus after striatal lesions as demonstrated by quantitative receptor autoradiography. J. Neurosci, 3:1189-1198.

Parent, A. (1986) Comparative Neurobiology of the Basal Ganglia. New York: John Wiley and Sons.

Paxinos, G., and C. Watson (1982) The Rat Brain in Stereotaxic Coordinates. New York: Academic Press.

Penney, J.B., and H.S. Pan (1986) Quantitative autoradiography of GABA and benzodiazepine binding in studies of mammalian and human basal ganglia functions. In C. Boast, E.W. Snowhill, and C.A. Altar (eds) Quantitative Receptor Autoradiography. New York: Alan R. Liss, Inc.

Penney, J.B., H.S. Pan, A.B. Young, K.A. Frey, and G.W. Dauth (1981) Quantitative autroradiography of $\left[{ }^{3} \mathrm{H}\right]$-muscimol binding in rat brain. Science 214:1036-1038.

Powers, A.S., and A. Reiner (1980) A stereotaxic atlas of the forebrain and midbrain of the Eastern Painted Turtle (Chrysemys picta picta). J. Hirnforsch. 21:125-159.

Reiner, A., and R.E. Carraway (1987) Immunohistochemical and biochemical studies on Lys $^{8} \cdot$ Asn $^{9}-$ Neurotensin ${ }^{8-13}$ (LANT6)- related peptides in the hasal ganglia of pigeons, turtles and hamsters. J. Comp. Neurol. 257:453-476.

Reiner, A., S.E. Brauth, and H.J. Karten (1984) Evolution of the amniote basal ganglia. Trends in Neuroscience 7:320-325.

Richfield, E.K, A.B. Young, and J.B. Penney (1986) Properties of D-2 dopamine receptor autoradiography: High percentage of high affinity agonist siles and increased nucleotide sensitivity in tissue sections. Brain Res. $383: 121-128$.

Richfield, E.K., D. DeBowey, J.B. Penney, and A.B. Young (1987) Basal ganglia and cerebral cortical distribution of dopamine D-1 and D-2 receptors in neonatal and adult cat brain. Neurosci Letters 73:203-208.

Robertson, H.A. (1986) Chronic D-amphetamine reverses the effect of corti cal lesions on striatal D.2 dopamine receptor density. Proc. Soc. Neurosci, 12:191 (abstract).
Selmon, L.D., and P.S. Goldman-Rakic (1985) Longitudinal topography and interdigitation of corticostriatal projections in the rhesus monkey. $J$ Neurosci 5:776-794.

Snider, R.S., and J.C. Lee (1961) A Stereotaxic Atlas of the Monkey Brain. $\$$ Chicago: The University of Chicago Press.

Snider, R.S., and W.T. Niemer (1961) A Stereotaxic Atlas of Cat Brain. Chicago: The University of Chicago Press.

Sokoloff, L. (1984) Metabolic Probes of Central Nervous System Activity in Experimental Animals and Man. Sunderland, MA: Sinauer.

Stoof, J.C., and J.W. Kebabian (1984) Minireview: Two dopamine receptors Biochemistry, physiology, and pharmacology. Life Sci 35:2281-2296.

Tassin, J.P., A. Cheramy, G. Blanc, A.M. Thierry, and J. Glowinsky (1976) Topographic distribution of dopamine innervation and of dopaminergic receptors in rat striatum. I. Microestimations of [ $\left.{ }^{3} \mathrm{H}\right] \mathrm{dop}$ mine uptake and dopamine content in microdiscs. Brain Res. 107:291-301.

Trugman, .J.M., W.A. Geary II, G.F. Wonten (1986) Localization of D.2 dopamine receptors to intrinsic striatal neurons by quantitative autoradiography. Nature 323:267-269.

Versteeg, D.H.G., J.Y.D. Gugten, W. De Jong, M. Palkovits (1976) Regional concentrations of noradrenaline and dopamine in rat brain. Brain Res 113:563-574.

Voorn, P., B. Jorritsma-Byhman, C. Van Dijk, and R.M. Buijs (1986) The dopaminergic innervation of the ventral striatum in the rat: $A$ light and electron-microscopical study with antibodies against dopamine. J. Comp. Neurol. 251:84-99

Wamsley, J.K. F.M. Filloux, D.R. Gehlert, and T.M. Dawson (1986) Lesions in the rat brain alter the density and distribution of dopamine D-1 and D-2 receptors as ascertained by quantitative autoradiography. Proc. Soc. Neurosci. 12:192 (abstract).

Weick, B.G., and J.R. Walters (1986) D-1/D-2 receptor coactivation induces potentiated responses in the activity of substantia nigra pars reticulata neurons in 6-hydroxydopamine lesioned rats. Proc. Soc. Neurosci. 12:488 (abstract).

Wright, A.K., and Arbuthnoll (1981) The pattern of innervation of the corpus striatum by the substantia nigra. Neuroscience 6:2063-2067. 